\title{
Approaches for Selective Oxidation of Methane to Methanol
}

\author{
Richa Sharma ${ }^{\mathbb{D}}$, Hilde Poelman $\mathbb{D}^{\text {, Guy B. Marin }} \mathbb{D}^{D}$ and Vladimir V. Galvita *(D) \\ Laboratory for Chemical Technology, Ghent University, Technologiepark 125, 9052 Ghent, Belgium; \\ richa.sharma@ugent.be (R.S.); Hilde.Poelman@UGent.be (H.P.); guy.marin@ugent.be (G.B.M.) \\ * Correspondence: vladimir.galvita@ugent.be; Fax +32-9-264-49-99
}

Received: 17 January 2020; Accepted: 31 January 2020; Published: 6 February 2020

\begin{abstract}
Methane activation chemistry, despite being widely reported in literature, remains to date a subject of debate. The challenges in this reaction are not limited to methane activation but extend to stabilization of the intermediate species. The low $\mathrm{C}-\mathrm{H}$ dissociation energy of intermediates vs. reactants leads to $\mathrm{CO}_{2}$ formation. For selective oxidation, nature presents methane monooxygenase as a benchmark. This enzyme selectively consumes methane by breaking it down into methanol. To assemble an active site similar to monooxygenase, the literature reports $\mathrm{Cu}-\mathrm{ZSM}-5$, Fe-ZSM-5, and $\mathrm{Cu}-\mathrm{MOR}$, using zeolites and systems like $\mathrm{CeO}_{2} / \mathrm{Cu}_{2} \mathrm{O} / \mathrm{Cu}$. However, the trade-off between methane activation and methanol selectivity remains a challenge. Density functional theory (DFT) calculations and spectroscopic studies indicate catalyst reducibility, oxygen mobility, and water as co-feed as primary factors that can assist in enabling higher selectivity. The use of chemical looping can further improve selectivity. However, in all systems, improvements in productivity per cycle are required in order to meet the economical/industrial standards.
\end{abstract}

Keywords: methane activation; chemical looping; methanol production

\section{Introduction}

Methane constitutes a major fraction of natural gas, coal bed gas, shale gas, and biogas. Despite being a classified greenhouse gas [1], its high calorific value, and ease of availability makes methane a widely consumed fuel in chemical industries and households. Combustion of methane is employed worldwide to produce energy at the cost of $\mathrm{CO}_{2}$ emissions. Selective conversion of methane to portable fuels, such as methanol, instead of its combustion, is an alternative greener route, which meets wide interests [2-4].

The global production of methanol today is more than 70 million tonnes per year, considering its broad application in the synthesis of products as well as its use as a blending component for transportation purposes [5,6]. Methanol is one of the first building blocks for a variety of synthetic materials, such as adhesives, paints, LCD screens, silicones, and pharmaceuticals, and can also be used to produce a range of chemicals, such as formaldehyde, olefins, propylene, and dimethyl ether. Out of the total methanol production, China alone produces $65 \%$, utilizing this fuel for transport as various blends from M5 to M100 [7].

Production of methanol was commercialized for the first time in 1923 by Mathis Pier at the Badische Anilin and Soda Fabrik (BASF). In this process, methanol was produced using syngas catalyzed by zinc chromite at $573-673 \mathrm{~K}$ and $30 \mathrm{MPa}[8,9]$. By the end of the 1920s, around 42,000 metric tonnes of methanol [10-12] was produced per year [8]. Currently, $60 \%$ of all methanol is synthesized using the Johnson Matthey industrial process, in addition to $25 \%$ by Lurgi, around $10 \%$ by Mitsubishi, and the remaining $5 \%$ by Kellog and others [13]. Moreover, the global methanol market is estimated to 
grow up to 48 billion US dollars by 2024 from its current worth of 25 billion US dollars in 2018 [14]. Improvement in methanol production is therefore essential to meet the increasing demands.

The syngas route, employed industrially for the production of methanol, is known as the indirect route. Herein, syngas is produced by steam reforming of methane (SRM), which is further converted to methanol by hydrogenation, as shown in Figure 1a [15-17]. Syngas generation in SRM incurs high capital and operating costs [18] in addition to gas compression and extensive heat transfer equipment $[12,18]$ requirements, which makes this process economically viable only on a large scale. The high temperature and pressure operations further entail a major decline in methanol selectivity due to syngas forming methane [19] or ethanol [20] as the primary by-products, along with minor amounts of acetone and methyl ethyl ketone, which are difficult to remove by distillation [21].

\section{a) Indirect Method}

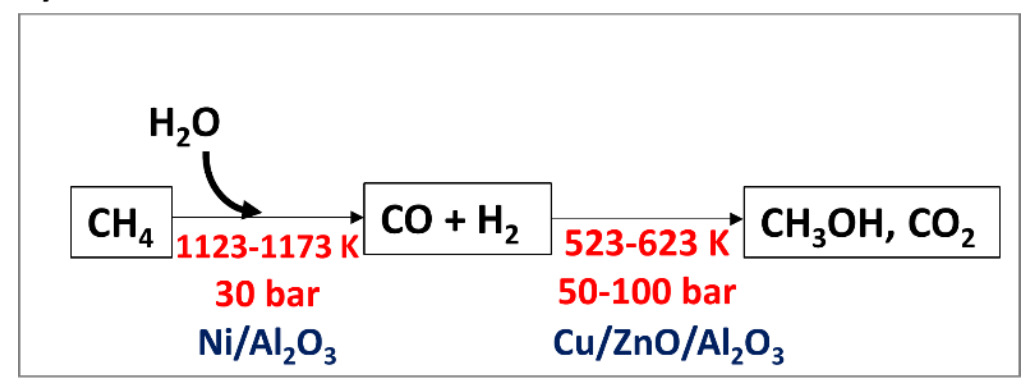

\section{b) Direct Method}

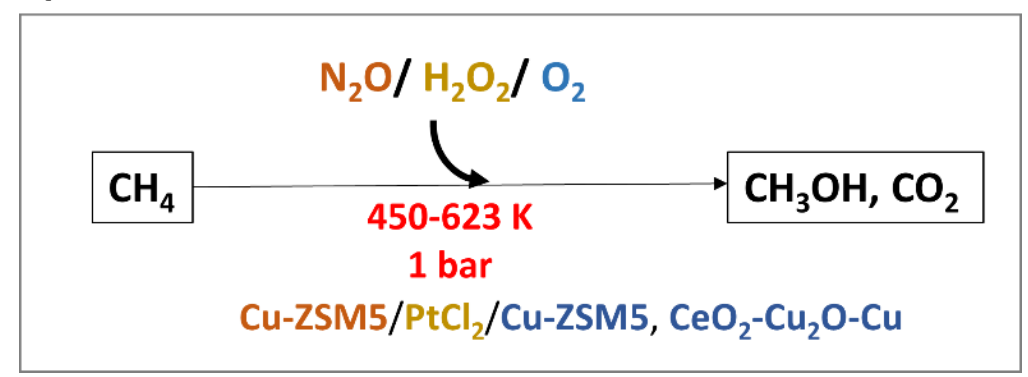

Figure 1. Overview of methane conversion to methanol using (a) the indirect method, which is carried out industrially via syngas. Gas compression, heat removal, and gas recycling make the indirect method only economically viable in a large-scale operation. Conversion of methane to methanol using (b) the direct method is an alternative promising route to meet the growing methanol demand [13].

In contrast to the indirect route, economical conversion of methane to methanol on a smaller scale, e.g., at remote oil extraction facilities to prevent methane flaring, is possible using a direct method [22,23]. The direct route, as shown in Figure 1b, circumvents intensive operational conditions as it bypasses the synthesis gas step, reduces cost, is more compact, and has higher conversion rates and higher selectivity $[23,24]$. These advantages have motivated researchers across the globe to test the activity of varying natural and synthetic catalytic materials and oxidants for direct conversion of methane to methanol (DMTM) as a potential alternative route to the conventional process.

\section{Direct Methane to Methanol (DMTM) Synthesis}

\subsection{DMTM in Nature}

DMTM occurs in nature uniquely by the action of methanotroph bacteria. Methanotrophs produce methane monooxygenase (MMO) enzymes, which are capable of oxidizing the $\mathrm{C}-\mathrm{H}$ bond of methane and consume it as a source of carbon and energy at an ambient temperature, as shown in Figure 2a [2,25]. These MMOs are found mostly in wetlands, rivers, rice paddies, oceans, deciduous woods, and sewage 
sludge, where the concentration of methane is high [25]. MMOs occur in two forms, as soluble and particulate enzymes (sMMO and pMMO), which activate methane by splitting molecular oxygen at its metal centers, followed by incorporating one atom of oxygen into methane. Oxygen binds to the metal centers forming metal-superoxo intermediates, which turns the kinetically inert ground state of $\mathrm{O}_{2}$ into a more reactive doublet state of $\mathrm{O}_{2}{ }^{-}$.

(a)

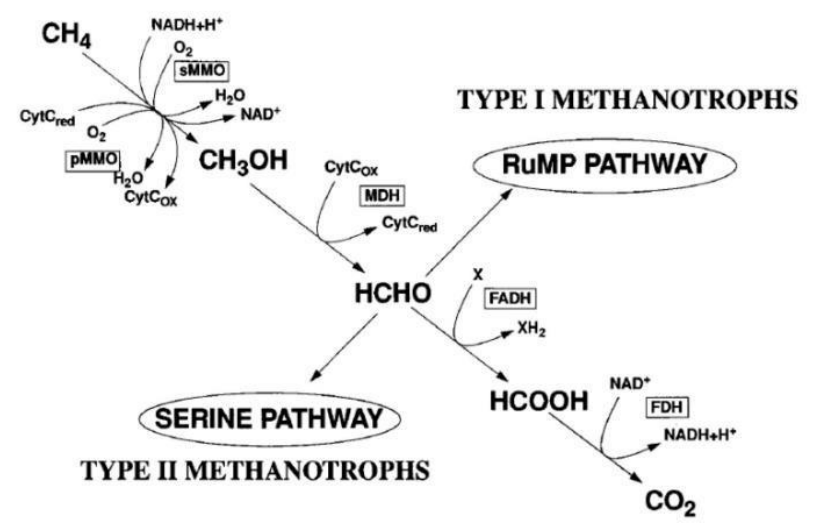

(b)

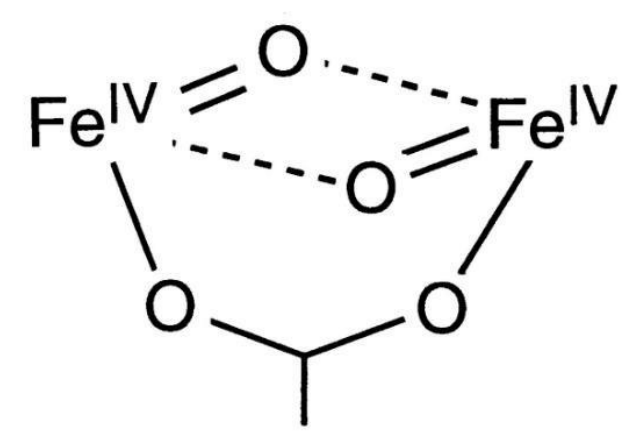

Figure 2. Methane consumption in nature by methanotrophs (MMO): (a) Proposed catalytic mechanism of di-iron active site in soluble methane monooxygenase (sMMO), which consumes methane to methanol [26,27]. Methanol produced further converts to formaldehyde and $\mathrm{CO}_{2}$ using enzymes, such as methanol dehydrogenase (MDH), formaldehyde dehydrogenase (FADH), and formate dehydrogenase (FDH) [25]. (b) The structure of the di-iron active site in sMMO [26,27].

The methane oxidation activity in sMMO is dependent on three proteins: the hydroxylase, regulatory component, and reductase. The active site in sMMO is a $\mu-1,2$ peroxo-bridged Fespecies, as shown in Figure $2 b$, also known as the di-iron site for oxygen activation and methane oxidation [28-34]. The coordinative interaction of the di-iron site with the hydroxylase protein and regulatory $\mathrm{B}$ component in $\mathrm{sMMO}$ transfers $\mathrm{OH}$ to the methyl radical, forming methanol. Methanol is then converted to formaldehyde by methanol dehydrogenase, which is further oxidized to form formate and to assimilate carbon.

In comparison to the iron based active centers in sMMO, pMMO contains a catalytic copper center [13,35]. In a recent report, Ross et al. [36] reported that pMMO consists of two mono-copper active sites, having an assembly of protein sub-units, $\mathrm{PmoB}$ and $\mathrm{PmoC}$, for methane binding and oxidation [36]. According to their study, methane oxidation to methanol in pMMO occurs in the presence of an electron donor, formaldehyde dehydrogenase (FADH), which generates hydrogen peroxide $\left(\mathrm{H}_{2} \mathrm{O}_{2}\right)$ at the PmoB site. The presence of a displaceable solvent ligand in PmoC further allows $\mathrm{H}_{2} \mathrm{O}_{2}$ to produce $\mathrm{OH}^{\bullet}$, which oxidizes methane [37]. These co-operative mechanisms enable MMOs to have $100 \%$ selectivity to methanol formation. However, despite the high methanol selectivity, the enzymatic productivity of sMMO and pMMO reported is $10^{-7}$ and $10^{-8} \mathrm{~mol} / \mathrm{g} / \mathrm{s}$, respectively $[38,39]$, which is far from the economical/industrial requirements of $10^{-6}$ to $10^{-4} \mathrm{~mol} / \mathrm{g} / \mathrm{s}$ [40].

Inspired by the active sites of MMOs, having $\mathrm{Cu}$ or Fe as the active metal, synthetic catalysts using these same metals supported on zeolites have been reported in literature for DMTM. Next to the metal center, the nature of the oxidant plays a critical role, in view of generating activated oxygen. Processes using liquid phase and gas phase oxidants for methane activation have been explored. Yet, in contrast to total oxidation, selective oxidation of methane and, in particular, the catalyst activity to selectively produce methanol is still very challenging. This review focuses on catalytic materials that have been reported to selectively activate methane to methanol, to the role of oxidants, and the challenges associated to these materials, as well as to the process and potential approaches to improve the DMTM performance. 


\subsection{Bio-Mimetic Zeolites: $\mathrm{H}_{2} \mathrm{SO}_{4}, \mathrm{H}_{2} \mathrm{O}_{2}$, and $\mathrm{N}_{2} \mathrm{O}$}

In Fe-ZSM5, besides the intrinsic chemistry of the active site, Szécsényi et al. [41] reported that a number of secondary variations in the local environment of bi-nuclear Fe(IV) clusters deposited in ZSM5 affects the activity towards $\mathrm{C}-\mathrm{H}$ activation in methane. These variations are destabilization of transition states (TS) and product states due to the confinement effect of the zeolite micropores, which causes a reactivity shift. The microporous structure of ZSM5 therefore has a key effect on the confinement of metal cations and active sites, which allows to form and stabilize high spin $\mathrm{Fe}^{\mathrm{IV}}=\mathrm{O}$ species [42].

Using concentrated sulfuric acid as the oxidant, Periana et al. [43,44] reported liquid phase activation of methane over $\mathrm{Hg}$ - and Pt-based catalysts. This process converts methane to methyl bisulfate, which subsequently oxidizes to methanol by hydrolysis. However, hydrolysis of methyl bisulfate to extract methanol and separation of the catalyst remain challenging in this process. Later, Hammond et al. [45] reported hydrogen peroxide $\left(\mathrm{H}_{2} \mathrm{O}_{2}\right)$ as oxidant in the liquid phase as feed (ex-situ) and also generated in-situ for DMTM. $\mathrm{H}_{2} \mathrm{O}_{2}$ reacts with di-iron centers of Fe-ZSM- 5 to produce methyl hydroperoxide as the primary product from methane. The unique diferric active site, containing one ferryl $(\mathrm{FeIV}=\mathrm{O})$ and one Fe-hydroperoxy $(\mathrm{Fe}-\mathrm{OOH})$, results in selective formation of methyl hydroperoxide, which further transforms to methanol. At $323 \mathrm{~K}$, they reported $10 \%$ maximum methane conversion and $93 \%$ methanol selectivity in a batch system [45]. Hutchings et al. also reported an array of catalysts viz., Fe-ZSM5 [46,47], CuFe-ZSM5 [48], Au-Pd nanoparticles [49,50], Au-Pd/TiO 2 [51], and $\mathrm{Au}-\mathrm{Pd}-\mathrm{Cu} / \mathrm{TiO}_{2}$ [52], viable in catalyzing selective oxidation of methane to methanol. Addition of $\mathrm{Cu}$ to Fe-ZSM5 was reported with higher methanol selectivity as $\mathrm{Cu}^{2+}$ is considered essential to retain methanol.

Furthermore, the trimeric $2.5 \% \mathrm{Au} 2.5 \% \mathrm{Pd} / 1.0 \% \mathrm{Cu} / \mathrm{TiO}_{2}$ catalyst was reported with $82.7 \%$ methanol selectivity in an ex-situ liquid phase process. $\mathrm{TiO}_{2}$ was reported inactive to the reaction, but addition of $\mathrm{Au}, \mathrm{Cu}$, and $\mathrm{Pd}$ increased methanol selectivity and reduced formation of formic acid [51]. Contrary to ex-situ $\mathrm{H}_{2} \mathrm{O}_{2}$ systems, the methane oxidation rate for in-situ systems using the same catalyst was reported low due to a competitive $\mathrm{Cu}$-catalyzed $\mathrm{H}_{2} \mathrm{O}_{2}$ reaction. Despite being environmentally benign, the use of expensive $\mathrm{H}_{2} \mathrm{O}_{2}$ as an oxidant is a significant limitation, which makes the process commercially less viable.

Using gas phase $\mathrm{N}_{2} \mathrm{O}$ as the oxidant, Panov et al. [53,54] and Starokon et al. [55,56] reported for the first time partial oxidation of methane on Fe-ZSM- $5 . \mathrm{N}_{2} \mathrm{O}$ as the oxidant on the surface of Fe-ZSM-5 was reported to create so-called $\alpha$-oxygen sites. Panov defines $\alpha$-oxygen as isolated ions or small complexes inside the ZSM- 5 channels. In this catalyst, the presence of Fe determines the activity of the catalyst. The activity of $\mathrm{Fe}$ to decompose $\mathrm{N}_{2} \mathrm{O}$ is two to three orders of magnitude higher than its ability to activate dioxygen. The low temperature decomposition of $\mathrm{N}_{2} \mathrm{O}$ on Fe- ZSM- 5 occurs via oxygen binding to the surface, creating $\alpha$-oxygen sites with 0.2 to $0.25 \mathrm{~N}_{2} \mathrm{O}$ molecules bound per Fe atom. This $\alpha$-oxygen is highly reactive and behaves similar to radical oxygen species, such as $\mathrm{O}^{-}$and $\mathrm{OH}^{\bullet}$. An $\alpha$-oxygen center in Fe-ZSM-5 is also postulated as a bis( $\mu$-oxo)di-iron(IV) unit that acts as the DMTM active moiety in this catalyst [57-59]. The presence of these active centers results in irreversible consumption of methane on the catalyst surface at room temperature, forming methoxy species which strongly bind to the surface. Desorption of methanol therefore requires higher temperatures, around 520-570 K in Fe-ZSM- 5, which easily leads to deeper oxidation products, such as $\mathrm{CO}_{\mathrm{x}}$ species, rather than methanol. Other than thermal desorption, solvent extraction of methanol has also been reported in literature, but this approach often leads to destruction of the active site.

Similar to Fe-ZSM-5, direct mimicry of the bio-enzymatic process has been considered widely using Cu-ZSM-5. In Cu-ZSM-5, $\left[\mathrm{Cu}_{2}(\mu-\mathrm{O})\right]^{2+}$ is reported as the core active site for direct conversion of methane to methanol, which could be activated by $\mathrm{N}_{2} \mathrm{O}$, as well as by di-oxygen as the oxidant [60]. 


\subsection{Bio-Mimetic Zeolites: $\mathrm{O}_{2}$ as Oxidant}

In Cu-ZSM-5 for DMTM, Lercher et al. [61] reported the presence of trinuclear $\left[\mathrm{Cu}_{3}(\mu-\mathrm{O})_{3}\right]^{2+}$ extra-framework complexes in addition to bis( $\mu$-oxo)dicopper $\left[\mathrm{Cu}_{2}(\mu-\mathrm{O})\right]^{2+}[60,62-64]$, which resembles the structure and reactivity of the active complex in the enzymatic system. Occurrence of these extra-framework complexes is largely based on the oxygen environment. Using periodic density functional theory (DFT) calculations with ab initio thermodynamic analysis, Li et al. [65] reported that under oxygen rich conditions, $\mathrm{Cu}-\mathrm{ZSM}-5$ activated at a high temperature shows the prevalence of trinuclear $\left[\mathrm{Cu}_{3}(\mu-\mathrm{O})_{3}\right]^{2+}[65]$. On the other hand, the binuclear $\left[\mathrm{Cu}_{2}(\mu-\mathrm{O})\right]^{2+}$ sites are the preferred species under relatively low $\mathrm{O}_{2}$ partial pressure.

Using di-copper oxo species with mixed valency, Mahyuddin et al. [24,66] recently reported a DFT study with bis( $\mu$-oxo) $\mathrm{Cu}^{\mathrm{II}} \mathrm{Cu}^{\mathrm{III}}$, ( $\mu$-oxo)( $\mu$-hydroxo) $\mathrm{Cu}^{\mathrm{II}} \mathrm{Cu}^{\mathrm{III}}$, and $\mathrm{Cu}^{\mathrm{III}} \mathrm{O}$ species in $\mathrm{pMMO}$, in addition to mono $(\mu-o x o) \mathrm{Cu}^{\mathrm{II}} \mathrm{Cu}^{\mathrm{II}}$ and $\operatorname{tris}(\mu-\mathrm{oxo}) \mathrm{Cu}^{\mathrm{II}} \mathrm{Cu}^{\mathrm{III}} \mathrm{Cu}^{\mathrm{III}}$ species in zeolites that can hydroxylate methane with reasonably low activation energies [67]. They found that it is the bridging oxygen atom that is highly reactive to cleave methane with an activation energy of $66 \mathrm{~kJ} / \mathrm{mol}$. By varying the zeolite structures, the geometry of $\left[\mathrm{Cu}_{2}(\mu-\mathrm{O})\right]^{2+}$ is altered, leading to different $\mathrm{Cu}-\mathrm{O}-\mathrm{Cu}$ angles that affect the catalytic activity. A possible catalytic cycle of methane to methanol on $\mathrm{Cu}$-zeolites, such as $\mathrm{Cu}$-AEI, $\mathrm{Cu}-\mathrm{CHA}, \mathrm{Cu}-\mathrm{AFX}$, and Cu-MFI, is shown in Figure 3a [66].

Mahyuddin et al. [66] suggested that when methane adsorbs on the Cu-ZSM-5 catalyst, the $\left[\mathrm{Cu}_{2}(\mu-\mathrm{O})\right]^{2+}$ active center causes homolytic dissociation of the $\mathrm{C}-\mathrm{H}$ bond of methane via the first transition state (TS-1), forming a methyl radical $\left[\mathrm{CH}_{3} \bullet \cdots \mathrm{HOCu}_{2}\right]^{2+}$-zeolite $[66,68]$. The radical hereafter either reacts with an $\mathrm{OH}$ ligand to directly form a product (methanol complex) via (TS-2) or it migrates to the $\mathrm{Cu}$-atoms to form a $\mathrm{Cu}-\mathrm{CH}_{3}$ bond, which recombines indirectly via (TS-2) to form methanol. Once methanol desorbs, it results in a final complex $[2 \mathrm{Cu}]_{2+}-$ zeolite $+\mathrm{CH}_{3} \mathrm{OH}$, while the bridging $\mathrm{O}_{\mathrm{oxo}}$ atom is regenerated via the third transition state (TS-3), thereby completing the catalytic cycle.

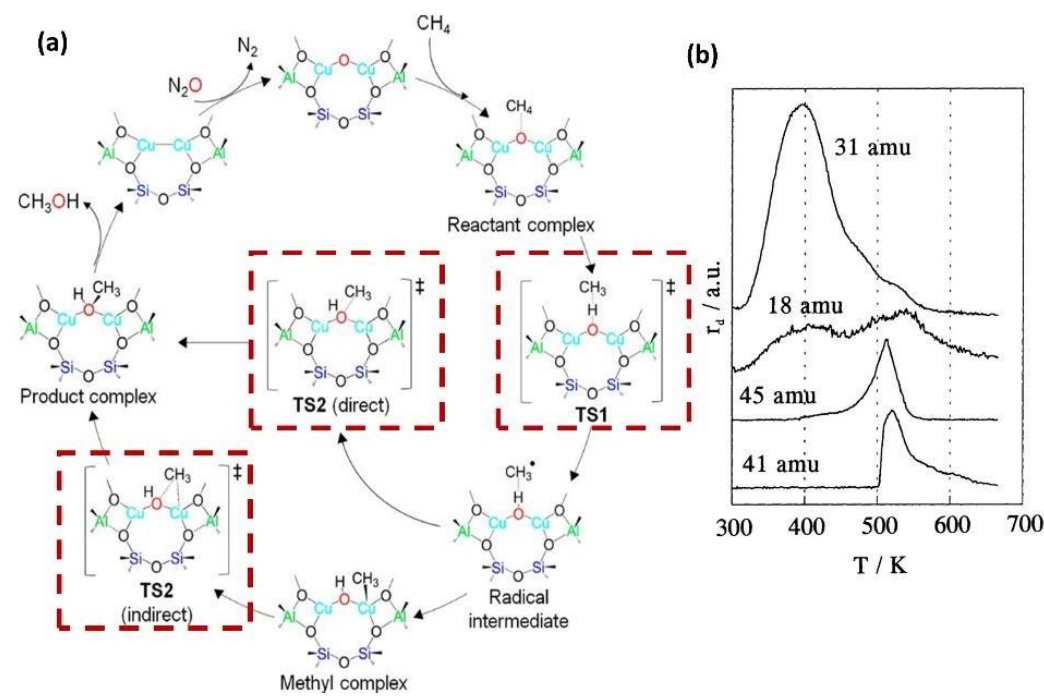

(c)

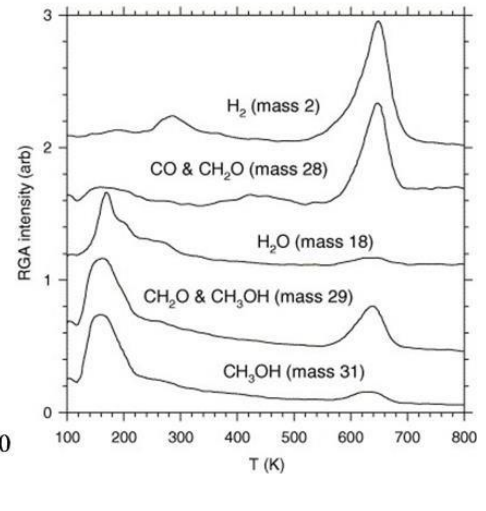

Figure 3. Methane conversion to methanol using $\mathrm{Cu}$ supported on zeolites: (a) A schematic catalytic cycle of methane to methanol conversion by bis( $\mu$-oxo)dicopper on zeolites such as -AEI, -CHA, -AFX, and -MFI, occurring via transition states (TS, shown in red boxes) [66]; (b) Temperature programmed desorption (TPD) results on HZSM-5 after adsorption of 2.5 methanol molecules per $\mathrm{Si}-\mathrm{OH}-\mathrm{Al}$ group (2.8 mmol g $\left.{ }^{-1}\right)$ : methanol (31 amu); water (18 amu); dimethyl ether (45 amu); $C_{3}-C_{5}$ hydrocarbons (41 amu); [69] and (c) TPD spectra of $\mathrm{CH}_{3} \mathrm{OH}$ adsorbed on $\mathrm{CeO}_{1.8}(111)$ at $90 \mathrm{~K}$ [70].

At $483 \mathrm{~K}$, the steady-state methanol production rates using Cu-Na ZSM-5 and Cu-H ZSM-5 were reported to be in the range of $10^{-10} \mathrm{~mol} / \mathrm{gcat} . / \mathrm{s}$ with a site time yield (STY) of $10^{-6} \mathrm{~mol} / \mathrm{mol}_{\mathrm{Cu}} / \mathrm{s}$ [71] . At this temperature, the methanol selectivity ranges from $70 \%$ to $98 \%$ for $\mathrm{Cu}$ - based ZSM- 5 and 
mordenite zeolites, respectively. Nevertheless, subsequent methanol desorption from the zeolites is quite challenging [71-73]. This is because the desorption activation energy for zeolites, such as $\left[\mathrm{Cu}_{2}(\mu-\mathrm{O})\right]^{2+}$-AEI, -CHA, -AFX, and -MFI, is quite high, amounting to $13,23,22$, and $29 \mathrm{~kJ} / \mathrm{mol}$, respectively [66]. Strong interaction of methanol with the cations in ZSM-5 causes up to 2.5 molecules being linked per cation at room temperature, which only completely desorb at $566 \mathrm{~K}$ [74]. Hence, although the active oxygen species in Cu-zeolites enable us to selectively activate methane to produce methanol, the acid strength of ZSM- 5 results in a higher temperature required for methanol desorption [75].

Temperature programmed desorption (TPD) profiles of methanol from ZSM-5, shown in Figure 3b, can be compared with methanol desorption from an oxide, such as ceria, as shown in Figure 3c. Methanol desorption from ZSM-5 occurs at 400-550 K, which often results in a fraction of methanol being dehydrated, yielding dimethyl ether [71] and formaldehyde, in addition to other minor products that are difficult to separate from each other $[13,55]$. Further increasing temperature results in poor methanol selectivity, with $\mathrm{CO}$ and $\mathrm{CO}_{2}$ as major products [73]. In comparison to zeolites, methanol desorption from ceria ranges between 150 to $250 \mathrm{~K}$, suggesting that methanol desorption is not hindered in ceria. In search of a material with optimum reducibility and acid-base characteristics for DMTM, metal oxides, such as ceria, can be considered as potential candidates.

\subsection{Metal Oxides: $\mathrm{O}_{2}$ as Oxidant}

Metal oxides, such as $\mathrm{MoO}_{3}$ [76,77], $\mathrm{V}_{2} \mathrm{O}_{5}$ [78], $\mathrm{La}_{2} \mathrm{O}_{3}$ [79], $\mathrm{SiO}_{2}$ [80], and $\mathrm{CeO}_{2}$ [81-83], are reported to activate methane in DMTM. Oxide surfaces are often considered to be "living", as in a breathing motion, as a result of the Mars-van Krevelen mechanism. As an example, Nibbelke et al. [84] reported an ${ }^{16} \mathrm{O}^{18} \mathrm{O}$ response during ${ }^{18} \mathrm{O}_{2}$ interaction with $\mathrm{Sn} / \mathrm{Li} / \mathrm{MgO}$. According to the Mars-van Krevelen mechanism, reactions on an oxide surface proceed via a redox mechanism, wherein catalyst lattice oxygen appears in the reaction products. Such occurrence leaves behind a surface vacancy, which is subsequently replenished by reoxidation through one of the reactants [85-87]. Pacchioni refers to this oxygen vacancy as the "invisible agent of oxide surfaces" [88]. He describes oxygen vacancies as point defects that represent the fingerprint of the electronic structure of the oxide. Exchange of lattice oxygen atoms through the Mars-van Krevelen mechanism may appear in the products of both selective and deep oxidation reactions [89].

Dissociation of methane is fairly facile on a metal oxide surface such as $\mathrm{IrO}_{2}(111)$ at temperatures as low as $150 \mathrm{~K}$ [90]. In this study, Liang et al. [90] reported that methane molecules bind very strongly to $\mathrm{IrO}_{2}$ (111), wherein the back donation of charge from the $\mathrm{Ir}_{\text {cus }}$ atom weakens the C-H bond of methane and promotes cleavage. Here, cus represents pairs of unsaturated $\mathrm{O}$ centers and cations on the $\mathrm{IrO}_{2}$ (111) surface, which acts in a cooperative way to dissociate the $\mathrm{C}-\mathrm{H}$ bond in methane. However, most of the adsorbed methane on $\mathrm{IrO}_{2}$ (111) easily oxidizes to $\mathrm{CO}, \mathrm{CO}_{2}$, and water [90]. Akin to $\mathrm{IrO}_{2}$ (111), Senftle et al. [91] reported a $\mathrm{Pd} / \mathrm{CeO}_{2}$ catalyst for low temperature activation of methane. Incorporation of $\mathrm{Pd}$ in ceria facilitates $\mathrm{Pd}^{4+} \leftrightarrow \mathrm{Pd}^{2+}$ transition enables rapid catalytic turnover. The fluorite lattice of ceria allows Pd atoms to change between octahedral and square planar coordination environments, leading to a facile Pd oxidation shift. This results in $\mathrm{O}_{2}$ oxidized $\mathrm{Pd}$ sites to serve as reduction centers for methane activation [91]. Hence, the methane oxidation rate on Pd-O-Ce linkages of a Pd/ceria catalyst is reported higher than on pure ceria [92]. Adsorption of methane on PdxCe1-xO $\mathrm{O}_{2}(111)$ results in the abstraction of $\mathrm{H}$ by the surface oxygen atom, forming $\mathrm{CH}_{3}{ }^{\circ}$. However, the subsequent adsorption of $\mathrm{CH}_{3}{ }^{\bullet}$ on the surface can lead to consecutive $\mathrm{C}-\mathrm{H}$ breaking steps that result in formation of $\mathrm{CO}_{2}$. Therefore, these studies indicate that, in addition to $\mathrm{C}-\mathrm{H}$ bond activation of methane, stabilization of the methyl species is a crucial factor in order to make selective oxidation of methane to methanol dominant over deep oxidation. Moreover, methanol dehydration to formaldehyde that further decomposes to $\mathrm{CO}$ is also a critical challenge.

Addressing the latter two challenges will require specifically pointing out the role of the lattice oxygen and then possibly laying out a strategy as to how methanol selectivity and yield could be 
enhanced over metal oxides. An essential element of this strategy is the question, whether it is just a material of choice that could enable a desired selectivity or is rather a process combined with a material that is more selective. Moreover, if a combination of process and material are of essence for selectivity, is this restricted to one specific material or can it include a range of materials with a specific inherent characteristic?

Insight in lattice oxygen mobility and its dynamic response characteristics [93], influencing methane activation and methanol selectivity, is therefore discussed and illustrated using DFT methods and spectroscopic studies reported in literature.

\subsubsection{Ceria Surfaces}

In ceria surfaces, the electronic and redox properties are dominated by oxygen vacancies, which account for its important role in vehicle exhaust treatment, water gas shift reaction, fuel cells, and CO oxidation reactions $[94,95]$. The O-vacancy formation energy is $30 \%$ lower on a ceria surface compared to its bulk $[96,97]$. Hence, ceria surfaces allow for easy exchange of $O$ between surface and adsorbates, which gives it the unique redox feature of excellent oxygen storage, as well as release. This implies ceria can exist as $\mathrm{CeO}_{2}, \mathrm{Ce}_{2} \mathrm{O}_{3}$, and other intermediate oxides, while retaining its original fluorite crystal structure [98]. Creation of an $\mathrm{O}$ vacancy results in two of the adjacent Ce cations to change the oxidation state from $\mathrm{Ce}^{4+}$ to $\mathrm{Ce}^{3+}$. Using spatially resolved scanning transmission electron microscopy - electron energy loss spectroscopy (STEM-EELS) experiments, Meledina et al. [99] reported Ce $\mathrm{M}_{4,5}$ edges acquired from the bulk and surface of reduced ceria nanopowder, as shown in Figure 4a-e. An undoped cerium nanoparticle (Figure 4a) was mapped (Figure 4d) based on the $\mathrm{Ce}^{4+}$ and $\mathrm{Ce}^{3+}$ elemental scans in Figure 4b,c. In addition, EELS spectra from two distinct areas were compared to reference spectra for $\mathrm{Ce}^{4+}$ and $\mathrm{Ce}^{3+}$ (Figure 4e). Reduced ceria showed significant $\mathrm{Ce}^{3+}$ contribution at its surface, while the bulk largely corresponded to $\mathrm{Ce}^{4+}$. Thus, as the surface contains higher $\mathrm{Ce}^{3+}$, more oxygen vacancies are present.
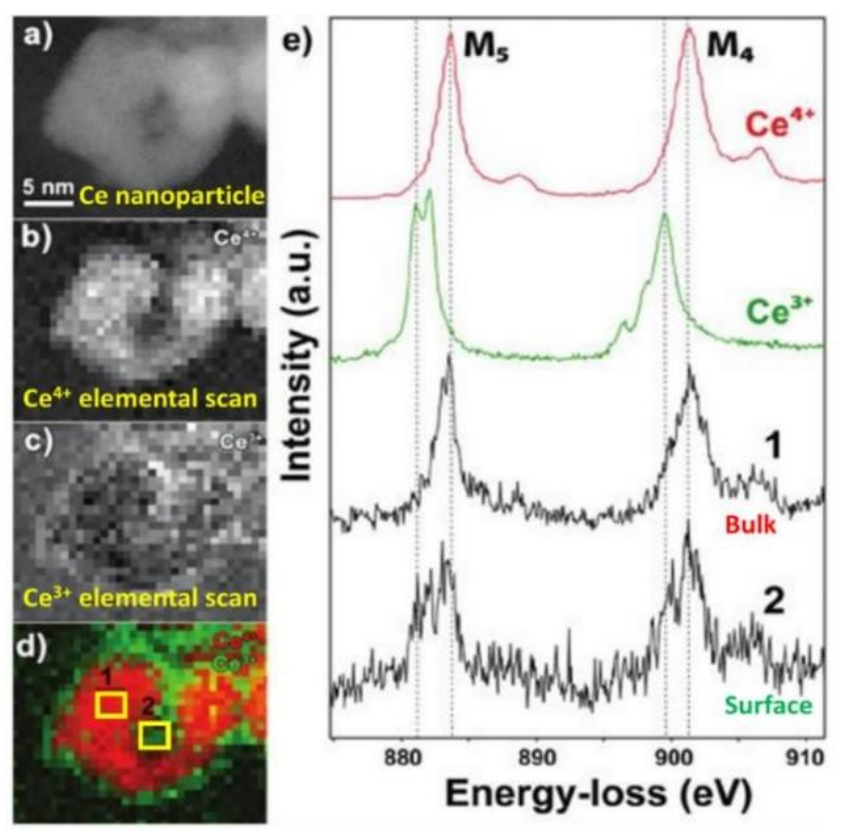

Figure 4. Surface reduction in undoped $\mathrm{CeO}$ : (a) High-angle annular dark-field scanning transmission electron microscopy (HAADF-STEM) overview image of several agglomerated ceria nanoparticles, (b) $\mathrm{Ce}^{4+}$ map, (c) $\mathrm{Ce}^{3+}$ map, (d) color map with $\mathrm{Ce}^{4+}$ (red) and $\mathrm{Ce}^{3+}$ (green), (e) reference EELS spectra for $\mathrm{Ce}^{3+}$ and $\mathrm{Ce}^{4+}$, together with spectra acquired from the core (1) and surface (2) of a ceria nanoparticle. 


\subsubsection{Doping}

Doped metal oxides exemplify unique chemical interactions between metal dopants and host oxides that are widely exploited to identify an optimal catalyst design. The ceria fluorite structure, with oxygen anion Frenkel defects (vacancies), allows us to generate solid solutions when a tetravalent cation in the host structure is replaced with a less positively charged ion [82,100]. Doping of a crystal structure with heteroatoms with a different valence than the original cation results in a charge imbalance that is typically compensated by creation of other defects in the structure [101]. The latter are responsible for the enhancement of oxide reducibility in $11 w t . \% \mathrm{CuO}-6 \mathrm{wt} . \% \mathrm{CeO}_{2} / \mathrm{Al}_{2} \mathrm{O}_{3}$, as reported by Menon et al. [102]. They incorporated $\mathrm{Cu}^{2+}$ ions, smaller than $\mathrm{Ce}^{4+}$, into $\mathrm{CeO}_{2}$ crystallites, thereby lowering the reduction temperature of the formed binary metal oxide. In this catalyst, copper existed either as large $\mathrm{CuO}$ monocrystalline particles or inside solid solution $\mathrm{Ce}_{1-\mathrm{x}} \mathrm{Cu}_{\mathrm{x}} \mathrm{O}_{2-\mathrm{x}}$ clusters, as shown in Figure 5. Hence, doping with heteroatoms increases the concentration of defects, thereby changing the chemical and physical properties of the oxide. These vacancies can improve the stabilization of deposited metal nanoparticles, which eventually tunes their chemical activity as well $[101,103,104]$.
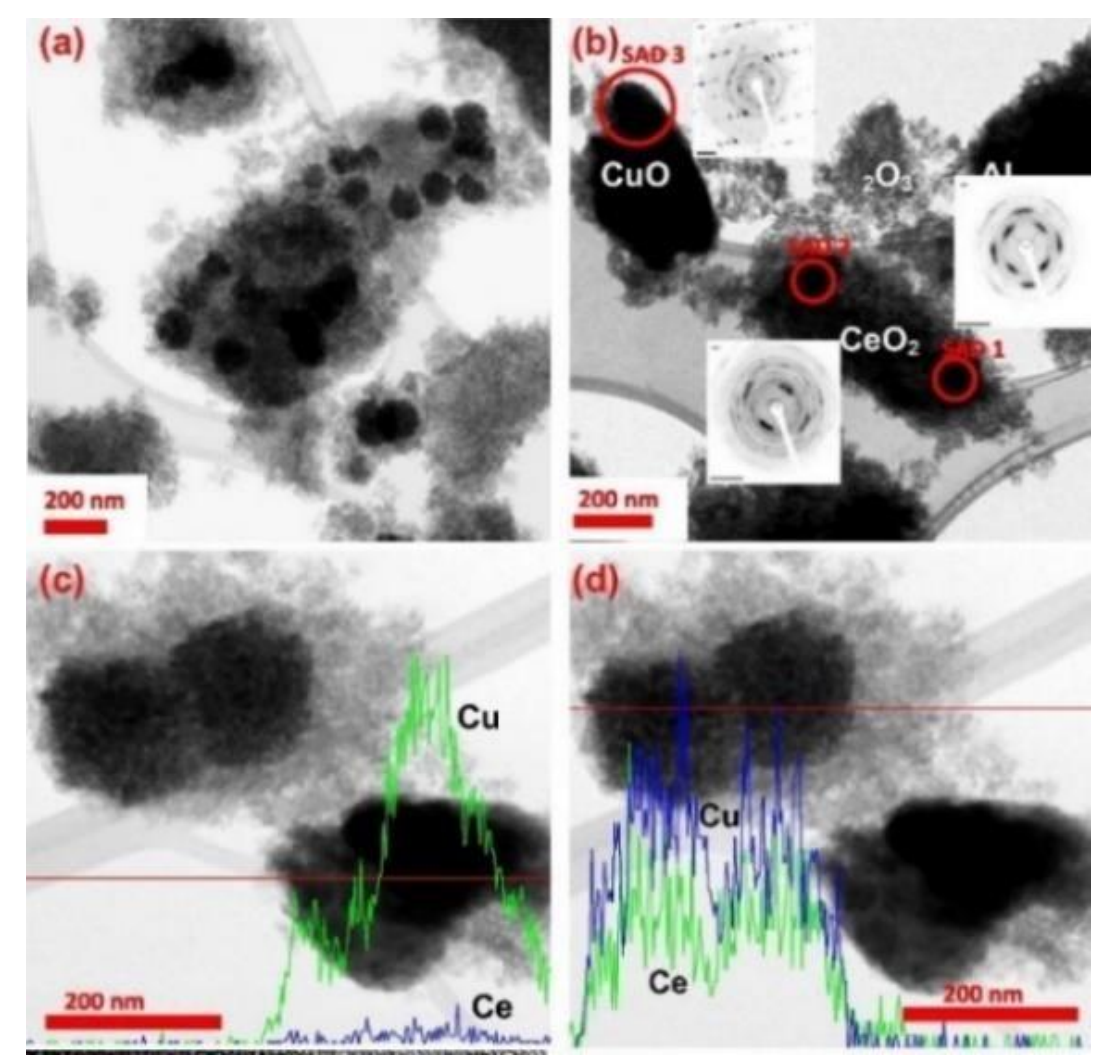

Figure 5. Transmission electron mission bright field (TEM BF) image of $11 w t . \% C u O-6 w t . \% \mathrm{CeO}_{2} / \mathrm{Al}_{2} \mathrm{O}_{3}$ : (a) Nanocrystals of $\mathrm{CeO}_{2}$ agglomerated into a cluster; (b) two types of $\mathrm{Cu}$-containing particles: $\mathrm{CuO}$ single crystallites $\left(\operatorname{sad}_{3}\right)$ and $\mathrm{Cu}$ dispersed in Ce-rich agglomerates $\left(\operatorname{sad}_{1}\right.$ and $\left.\operatorname{sad}_{2}\right)$; elemental line scan through; (c) $\mathrm{CuO}$ single crystallites; and (d) $\mathrm{Ce}_{1-x} \mathrm{Cu}_{\mathrm{x}} \mathrm{O}_{2-\mathrm{x}}$ solid solution.

Probing the redox properties of ceria, Mayenick and Janik (2008) [91,92] reported that the $\mathrm{CH}_{4}$ energy of adsorption on a ceria surface is dependent on the surface reducibility. Since the latter is measured as the oxygen vacancy formation energy, Pd-containing surfaces in Figure 6 exhibit the most exothermic vacancy formation, as well as adsorption energies, followed by $\mathrm{Zr}$ - substituted ceria and lastly pure ceria. The linear correlation between vacancy formation and methane adsorption is based on the fact that both are reduction processes [92]. Thus, dissociative methane adsorption is directly related to vacancy formation. 


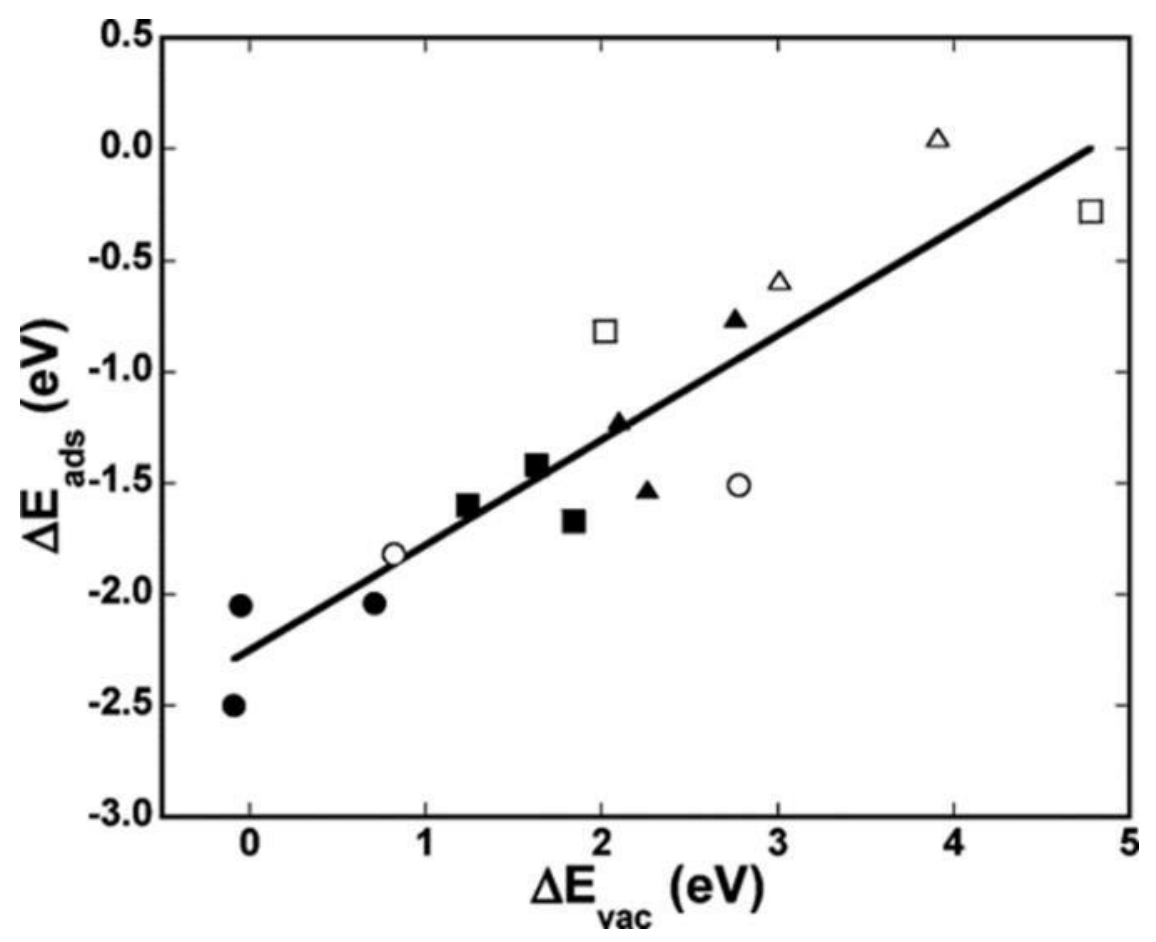

Figure 6. DFT calculated correlation between methane adsorption energy and surface vacancy formation energy: Methane adsorption energy ( $\Delta$ Eads) vs. surface vacancy formation energy $(\Delta$ Evac)

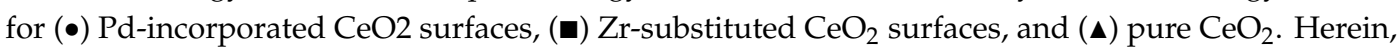
the pre-reduced surfaces are noted by open symbols. This plot shows the dependence of methane adsorption energy on surface reducibility, with Pd-ceria being more reducible than pure ceria [92].

To gauge the activity of metal-doped ceria for methane activation, Tian et al. [100] compared C-H bond dissociation between the pure $\mathrm{CeO}_{2}(110)$ surface and a Co-substituted $\mathrm{CeO}_{2}(110)$. They reported that cobalt substitution greatly facilitates $\mathrm{C}-\mathrm{H}$ bond activation by reducing the adsorption energy from 1.7 to $0.8 \mathrm{eV}$ at the transition state in the $\mathrm{O}_{\mathrm{a}}$ site, as calculated by DFT [100]. Singha et al. [105] reported that the distance between a surface cerium atom and an interfacial $\mathrm{O}$ atom increases with the addition of a $\mathrm{Ni}_{4}$ cluster, which draws the surface $\mathrm{O}$ atoms of ceria outward from the surface plane. This increase in bond distance makes $\mathrm{O}$ atoms very reactive for methane activation. Similarly, Zhang et al. [82] reported methane decomposition using ceria supported metal oxides $\left(\mathrm{MO}_{\mathrm{x}}\right)$ with $\mathrm{M}=\mathrm{Cu}, \mathrm{Ni}$, and $\mathrm{Fe}$. With each of these metals, the $\mathrm{MO}_{\mathrm{x}}$ ad-layer changes the reducibility of ceria, and the interface between metal and oxide is strongly affected by the presence of oxygen vacancies. This resulted in adsorption of methane on $\mathrm{MO}_{\mathrm{x}} / \mathrm{CeO}_{2}$, while none occurred with plain ceria. Moreover, methane, being a reducing gas, results in a change in the oxidation state of the metal oxide, as well as the support, with $\mathrm{CuO}_{\mathrm{x}} / \mathrm{CeO}_{2}$ being reduced most easily (at $533 \mathrm{~K}$ ), while $\mathrm{FeO}_{\mathrm{x}} / \mathrm{CeO}_{2}$ is more difficult to reduce (at $840 \mathrm{~K}$ ). Further, methane consumption on metallic $\mathrm{Cu}_{0}$ is ineffective in contrast to $\mathrm{Fe}_{0}$ and $\mathrm{Ni}^{0}$. Complete methane decomposition was reported using $\mathrm{Fe}^{0} / \mathrm{CeO}_{2-x}$ followed by $\mathrm{Ni}^{0} / \mathrm{CeO}_{2-x}$ and then $\mathrm{Cu}^{0} / \mathrm{CeO}_{2}$. The high reactivity of $\mathrm{Fe}^{0} / \mathrm{CeO}_{2-\mathrm{x}}$ led to more intense $\mathrm{CH}_{\mathrm{x}}$ and $\mathrm{CO}_{\mathrm{x}}$ groups being detected in X-ray photoelectron spectroscopy (XPS) at 284.5 and $290 \mathrm{eV}[82,106]$, as presented in Figure $7 \mathrm{a}$, while completely decomposing methane to $\mathrm{H}_{2}, \mathrm{CO}, \mathrm{CO}_{2}$, and water at temperatures up to $840 \mathrm{~K}$, as shown in Figure $7 \mathrm{~b}$.

An interesting synergy between the distortion of the oxygen polyhedra in ceria and the amount of dopant content was reported by Sadykov et al. [107] Incorporation of $\mathrm{Sm}^{3+}$ and $\mathrm{Bi}^{3+}$ as dopant into ceria with $\mathrm{Pt}$ as the active metal enhanced lattice oxygen mobility, which resulted in partial oxidation of methane to syngas. They reported that the residual lattice hydroxyls in pure ceria strongly distort its oxygen polyhedra. This distortion can be reduced by doping a metal into the support, e.g., $\mathrm{Ce}_{1-x} \mathrm{Sm}_{x} \mathrm{O}_{2}$. 
At low dopant content, anion vacancies appear, which relax the structure, thereby minimizing the polyhedral distortion. On the other hand, at high dopant content, polyhedral distortion increases, resulting in a compete structural re-arrangement. Correlating these structural changes in terms of activity, they reported that the presence of anion vacancies and surface defects at low dopant contents selectively yields syngas, while at high dopant content only deep oxidation products, such as $\mathrm{CO}_{2}$, were observed. The addition of $\mathrm{Pt}$ to $\mathrm{Ce}_{1-x} \mathrm{Sm}_{x} \mathrm{O}_{2}$ (at low dopant content) further improves reducibility, thereby enhancing the syngas selectivity.
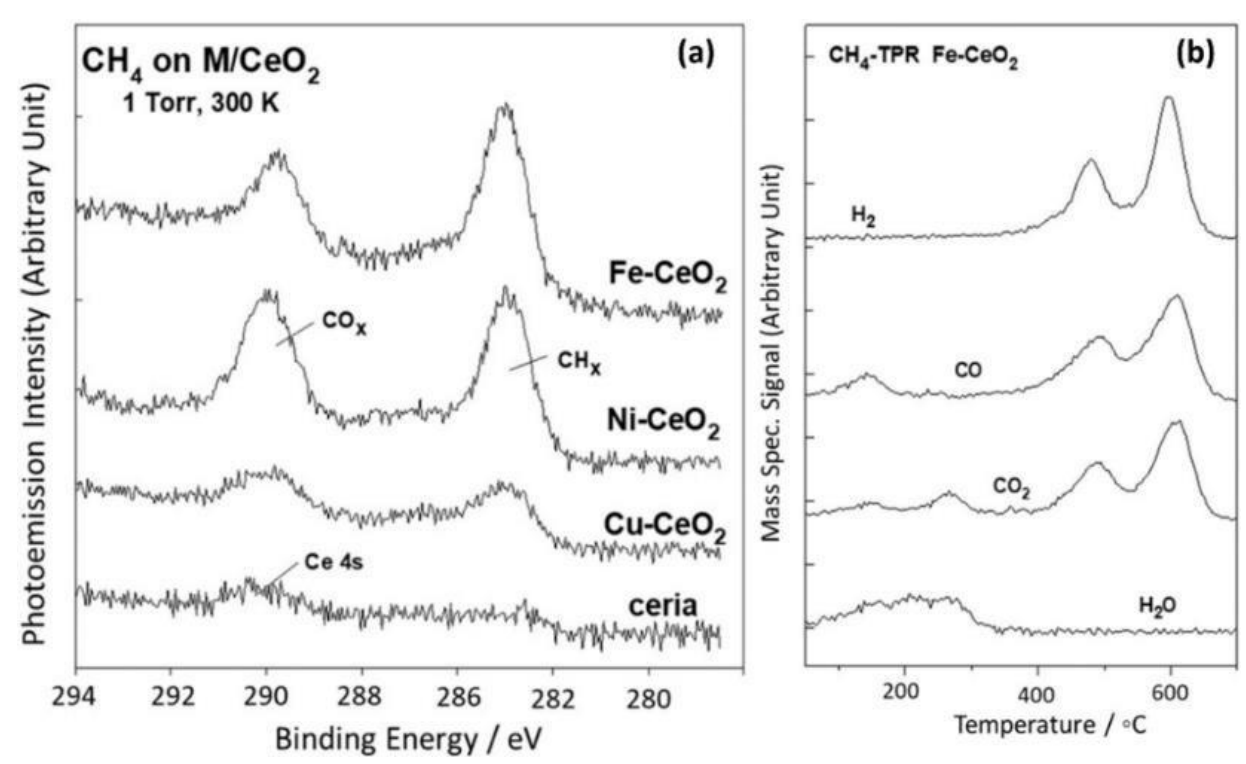

Figure 7. Methane adsorption on ceria and ceria supported catalysts: (a) C1s XPS spectra collected after exposing $\mathrm{CeO}_{2}$ and $\mathrm{MOx} / \mathrm{CeO}_{2}$ catalysts $(\mathrm{M}=\mathrm{Cu}, \mathrm{Ni}$, or $\mathrm{Fe})$ to a 0.00133 bar of methane at $25^{\circ} \mathrm{C}$ for 5 min. (b) Evolution of $\mathrm{CO}, \mathrm{CO}_{2}, \mathrm{H}_{2}$, and $\mathrm{H}_{2} \mathrm{O}$ products during $\mathrm{CH}_{4}$ - $\mathrm{TPR}$ on $\mathrm{FeO}_{\mathrm{x}} / \mathrm{CeO}_{2}$ heated to $700{ }^{\circ} \mathrm{C}$ at a ramp rate of $10{ }^{\circ} \mathrm{C} / \mathrm{min}$ under a flow of $10 \mathrm{~cm}^{3} / \mathrm{min}$ flow of $5 \% \mathrm{CH}_{4}$ in Helium [82].

Thus, the oxygen storage capacity (OSC) of ceria improves by introducing a dopant cation. A dopant increases the amount of oxygen vacancies, leading to enhanced oxygen mobility and, hence, reducibility. However, the outcome of higher oxygen mobility is higher catalytic activity, which could easily lead to complete oxidation.

In order to perform selective oxidation, an ideal oxygen carrier, therefore, must have an "intermediate" surface M-O bond strength and "intermediate" mobility of lattice $\mathrm{O}$ atoms in order to be both selective and active [108]. A weak M-O bond will release $\mathrm{O}$ atoms very easily, resulting in reactants undergoing complete oxidation. In contrast, a strong $\mathrm{M}-\mathrm{O}$ bond implies that the material is a weak oxidant. One way to control the $\mathrm{M}-\mathrm{O}$ bond strength is by changing its reduction degree. For instance, Menon et al., [109] reported $\mathrm{CuO}-\mathrm{CeO}_{2} / \mathrm{Al}_{2} \mathrm{O}_{3}$, pre-treated with dioxygen, showing a decrease in the rate of toluene total oxidation with an increasing degree of catalyst reduction. However, no change in the product selectivity was observed with increasing degree of reduction. This suggests that, other than the oxidation state of the catalyst, it is rather the oxidant that might play a critical role in changing the product selectivity. The oxidant nature dictates its interaction with the catalyst, allowing only certain sites to be activated depending on its oxidation potential. Hence, at a given operating temperature, the sites activated using oxygen as the oxidant will not be the same if a softer oxidant, such as $\mathrm{CO}_{2}$ or water, is used. Apart from the oxidizing ability, soft oxidants minimize secondary reactions to occur, which otherwise often result in the formation of deep oxidation products. Moreover, the energy required to form $\mathrm{O}$ vacancies, $\Delta \mathrm{E}_{\mathrm{vac}}$, can be tuned using soft oxidants in order to sustain a sufficient concentration of vacancies that can reach the surface, while avoiding too high oxygen mobility [108]. 


\section{From Methane Activation to Methanol Selectivity}

The most challenging factor in the direct methane to methanol route is to achieve enhanced methanol selectivity at a reasonable methane conversion. In this context, some studies have reported that the presence of water can steer a catalytic cycle to selectively produce methanol. This function involves water taking up a role as promoter. To do so, dissociation of water on a suitable material is required, whereby the $\mathrm{OH}$ formed aid in stabilizing the methyl species.

One such material is the inverse catalyst $\mathrm{CeO}_{2} / \mathrm{Cu}_{2} \mathrm{O} / \mathrm{Cu}$. "Inverse catalyst" is a term coined by Rodriguez et al. [110], which refers to the configuration of oxide nanoparticles supported on a metallic substrate. An inverse catalyst therefore exposes the oxide nanoparticles to the reactants and allows reactants to interact with the defect sites in oxides, the metal sites, and the metal-oxide interface [110]. Using DFT calculations, Rodriguez et al. [111] reported that dissociation of water on $\mathrm{Ce}_{6} \mathrm{O}_{13} / \mathrm{Cu}(111)$ is exothermic in nature with a $\Delta \mathrm{E}$ value of $-0.33 \mathrm{eV}$ and an activation energy lower than $0.35 \mathrm{eV}$. The same was also verified using XPS, showing partial dissociation of water to $\mathrm{OH}$ and $\mathrm{H}$ at $300 \mathrm{~K}$ [111].

Under water gas shift (WGS) conditions, Senanayake et al. [112] reported that the inverse catalyst $\mathrm{CeO}_{2} / \mathrm{Cu}_{2} \mathrm{O} / \mathrm{Cu}$ transforms into $\mathrm{CeO}_{x} / \mathrm{Cu}$, while water dissociation is the rate-limiting step. To assess activity, they made a direct comparison between $\mathrm{Cu}$ nanoparticles supported on ceria and $\mathrm{CeO}_{\mathrm{x}} / \mathrm{Cu}$, as presented in Figure 8. The inverse catalyst has considerably better activity, indicating that the interaction between the oxide nanoparticles and $\mathrm{Cu}$, in particular at the interface, is unique in facilitating water dissociation. In inverse oxides, defect sites of the oxides are no longer covered by the metal as in the case of traditional metal/oxide catalysts, so that they give higher activity. [87] Several authors have reported that the presence of $\mathrm{O}$ vacancies and edge atoms in ceria nanoparticles drastically affects their reactivity towards $\mathrm{CO}, \mathrm{CO}_{2}, \mathrm{O}_{2}$, and $\mathrm{H}_{2} \mathrm{O}$ [112-114]. Paier et al. [115] also suggested that oxygen vacancies in ceria promote decomposition of water molecules into active $\mathrm{OH}$ species, thereby providing an active catalyst surface in the presence of water vapor [94].

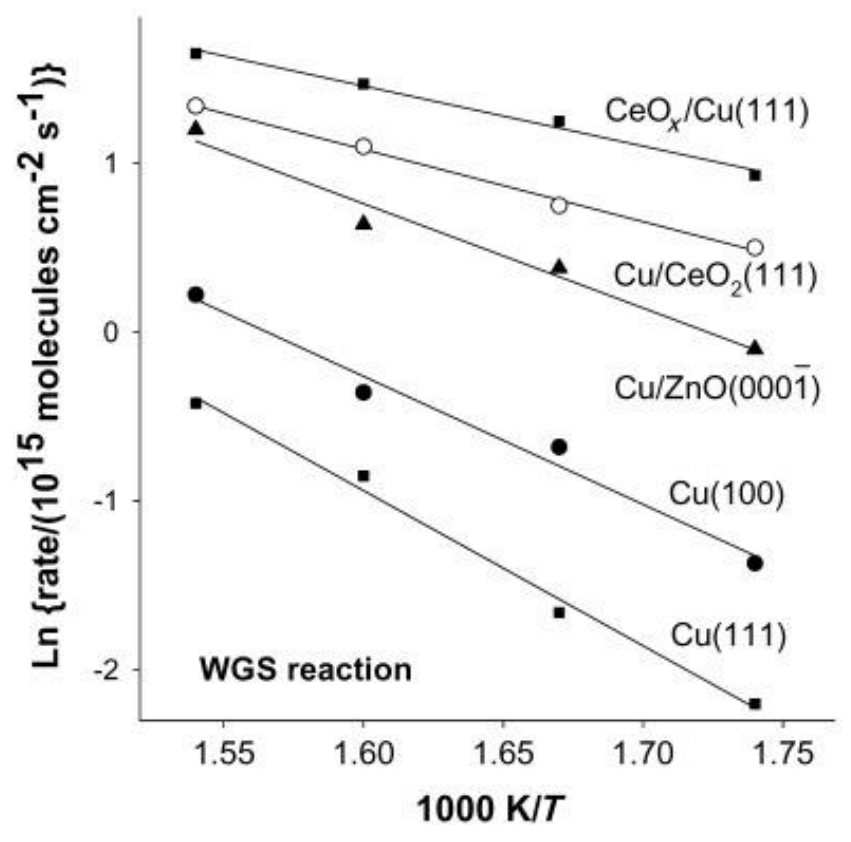

Figure 8. Arrhenius plot for the water gas shift (WGS) reaction rate on clean $\mathrm{Cu}(111)$ and $\mathrm{Cu}(100)$, as well as on a copper surface, approximately $20 \%$ covered by ceria. The $\mathrm{CeO}_{x} / \mathrm{Cu}(111)$ surface was prepared by dosing $\mathrm{Ce}$ to $\mathrm{Cu}(111)$ at $650 \mathrm{~K}$ under an atmosphere of $\mathrm{O}_{2}\left(p \sim 5 \times 10^{-7}\right.$ Torr). A total of 0.5 the monolayer (ML) of $\mathrm{Cu}$ vapor was deposited on $\mathrm{CeO}_{2}(111)$, and $\mathrm{ZnO}(0001)$ surfaces were taken as reference. These reference catalysts were prepared at room temperature and heated further to water gas shift (WGS) temperatures, between 574 and 649 K [111]. 
Using $\mathrm{CeO}_{2} / \mathrm{Cu}_{2} \mathrm{O} / \mathrm{Cu}$, Zuo et al. [83] also reported low temperature activation of methane to methanol in presence of water. Incorporation of ceria into $\mathrm{Cu}(111)$ under an oxygen atmosphere leads to formation of $\mathrm{Cu}_{2} \mathrm{O}(111)$, with two types of ceria islands on top: small islands ( $2-5 \mathrm{~nm}$ in size, $\mathrm{CeO}_{\mathrm{x}-\mathrm{I}}$ ) on the copper terrace and large islands $\left(30-50 \mathrm{~nm}\right.$ in size, $\left.\mathrm{CeO}_{\mathrm{x}-\mathrm{II}}\right)$. These islands were visualized using scanning tunneling microscope (STM) by Rodriguez et al. [111] and Yang et al. [116] on the substrate edges, as shown in Figure 9a.

(a)

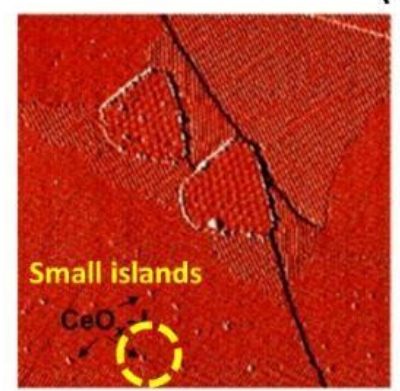

$200 \times 200 \mathrm{~nm}^{2}$

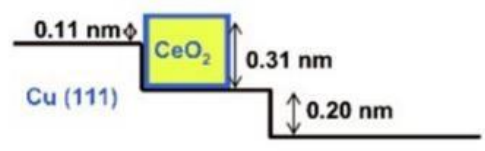

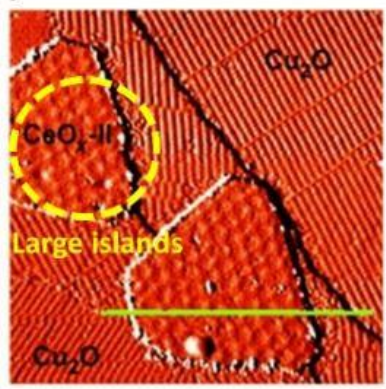

$100 \times 100 \mathrm{~nm}^{2}$

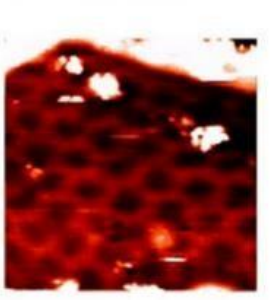

$30 \times 30 \mathrm{~nm}^{2}$ (b)

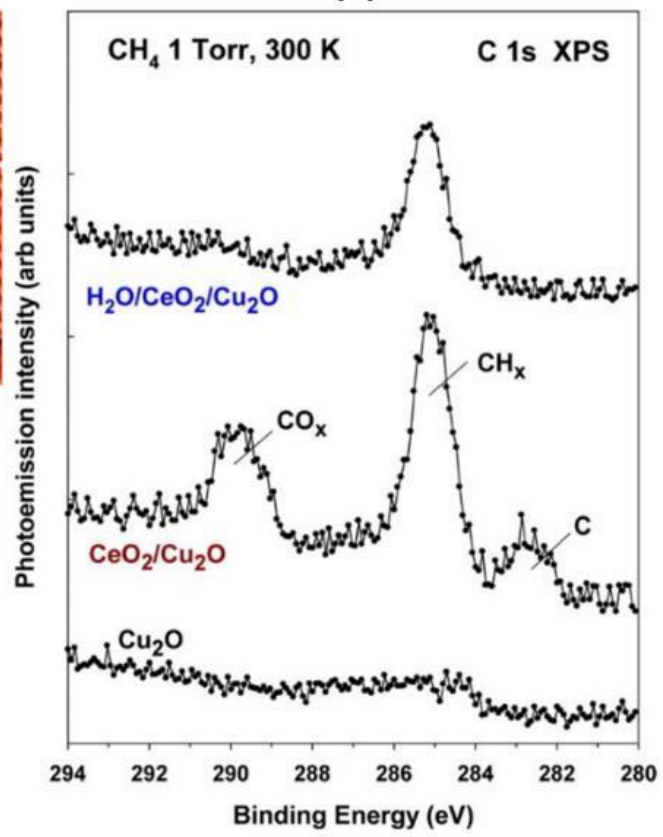

Figure 9. Inverse catalyst: (a) STM images recorded after dosing $\mathrm{Ce}$ to $\mathrm{Cu}(111)$ at $650 \mathrm{~K}$ under an atmosphere of $\mathrm{O} 2\left(\mathrm{p} \sim 5 \times 10^{-7}\right.$ Torr). The yellow circles show the presence of two types of ceria islands, where ceria is deposited on a copper oxide $\mathrm{Cu}_{2} \mathrm{O}$. Structural analysis of these islands with a height of $0.31 \mathrm{~nm}$ leads to representation of a O-Ce-O-Cu stacking at its interface [110,111]; (b) C1s XPS spectra collected after exposing $\mathrm{Cu}_{2} \mathrm{O} / \mathrm{Cu}(111), \mathrm{CeO}_{2} / \mathrm{Cu}_{2} \mathrm{O} / \mathrm{Cu}(111)$, and $\mathrm{H}_{2} \mathrm{O} / \mathrm{CeO}_{2} / \mathrm{Cu}_{2} \mathrm{O} / \mathrm{Cu}(111)$ to $1 \mathrm{Torr}$ of methane at $300 \mathrm{~K}$ for $5 \mathrm{~min}$. In $\mathrm{CeO}_{2} / \mathrm{Cu}_{2} \mathrm{O} / \mathrm{Cu}(111), 40 \%$ of $\mathrm{Cu}_{2} \mathrm{O}$ was covered by ceria. The $\mathrm{CeO}_{2} / \mathrm{Cu}_{2} \mathrm{O} / \mathrm{Cu}(111)$ surface was exposed to 50 Langmuir of water at $300 \mathrm{~K}$ to generate $\mathrm{H}_{2} \mathrm{O} / \mathrm{CeO}_{2} / \mathrm{Cu}_{2} \mathrm{O} / \mathrm{Cu}(111)$. The absence of $\mathrm{C}$ and $\mathrm{CO}_{x}$ on $\mathrm{H}_{2} \mathrm{O} / \mathrm{CeO}_{2} / \mathrm{Cu}_{2} \mathrm{O} / \mathrm{Cu}(111)$ shows absolute selectivity for $\mathrm{CH}_{\mathrm{x}}$ species, thereby indicating no decomposition of $\mathrm{CH}_{4}$ to $\mathrm{C}$ or $\mathrm{CO}_{2}$. [83].

At small and medium coverages of ceria $(<0.5$ monolayer $(\mathrm{ML}))$, these islands appear as a single layer of $(\mathrm{O}-\mathrm{Ce}-\mathrm{O}-\mathrm{Cu})$ stacking. The ability of ceria to dissociate water into $\mathrm{OH}$ and $\mathrm{H}$ results in $\mathrm{OH}$ anchored to $\mathrm{CeO}_{2} / \mathrm{Cu}_{2} \mathrm{O} / \mathrm{Cu}$ with high lying $\mathrm{O} 2 \mathrm{p}$ states that are more active in attracting and dissociating methane. In the case of $\mathrm{Cu}_{2} \mathrm{O} / \mathrm{Cu}$, these adsorbed $\mathrm{OH}$ remain embedded in the hexagonal cavity of the $\mathrm{Cu}_{2} \mathrm{O}$ surface, which makes interaction with methane difficult. The activation barrier for dissociation of methane using $\mathrm{Cu}_{2} \mathrm{O} / \mathrm{Cu}$ lies around $1.6 \mathrm{eV}$, while for $\mathrm{CeO}_{2} / \mathrm{Cu}_{2} \mathrm{O} / \mathrm{Cu}$, interfacial $\mathrm{Ce}^{4+}$ at the O-sites helps to dissociate methane to methyl with an activation energy of $0.5 \mathrm{eV}$ [83]. Moreover, the adsorbed $\mathrm{OH}$ occupies part of the surface sites that are otherwise responsible for complete decomposition of methane to $\mathrm{C}$ and $\mathrm{CO}_{\mathrm{x}}$ species. This blocking of methane decomposition sites allows $\mathrm{CeO}_{2} / \mathrm{Cu}_{2} \mathrm{O} / \mathrm{Cu}$ to enhance methanol selectivity in the presence of water, as shown in Figure $9 \mathrm{~b}$.

In addition to ceria, $\mathrm{Cu}_{2} \mathrm{O}$ in itself does not play a very significant role in methane dissociation. As a promoter, it could serve as a water gas shift catalyst. However, a precise mechanism of the set of consecutive events has not been reported to date. With this study [83], Zuo et al. claim that at $450 \mathrm{~K}$ in the presence of water, $\mathrm{CeO}_{2} / \mathrm{Cu}_{2} \mathrm{O} / \mathrm{Cu}$ converts methane directly to methanol. Moreover, the ceria 
nanoparticles deposited onto $\mathrm{Cu}_{2} \mathrm{O}$ were also reported to be efficient for adsorbing and dissociating $\mathrm{O}_{2}$ molecules with a subsequent spillover of $\mathrm{O}$ to the copper substrate and an enhancement in the rate of $\mathrm{CuO}_{x}$ formation. With less than $50 \%$ coverage of copper oxide by ceria, the ceria islands only consist of a single layer with $\mathrm{O}-\mathrm{Ce}-\mathrm{O}-\mathrm{Cu}$ stacking. This single stack is considered active for methane activation, which, along with excess water, enables higher methanol production than $\mathrm{CO}$ and $\mathrm{CO}_{2}$. At $450 \mathrm{~K}$ and $50 \%$ coverage, these inverse catalysts show a methanol to $\mathrm{CO}$ and $\mathrm{CO}_{2}$ ratio close to 3:1, as shown in Figure 10.

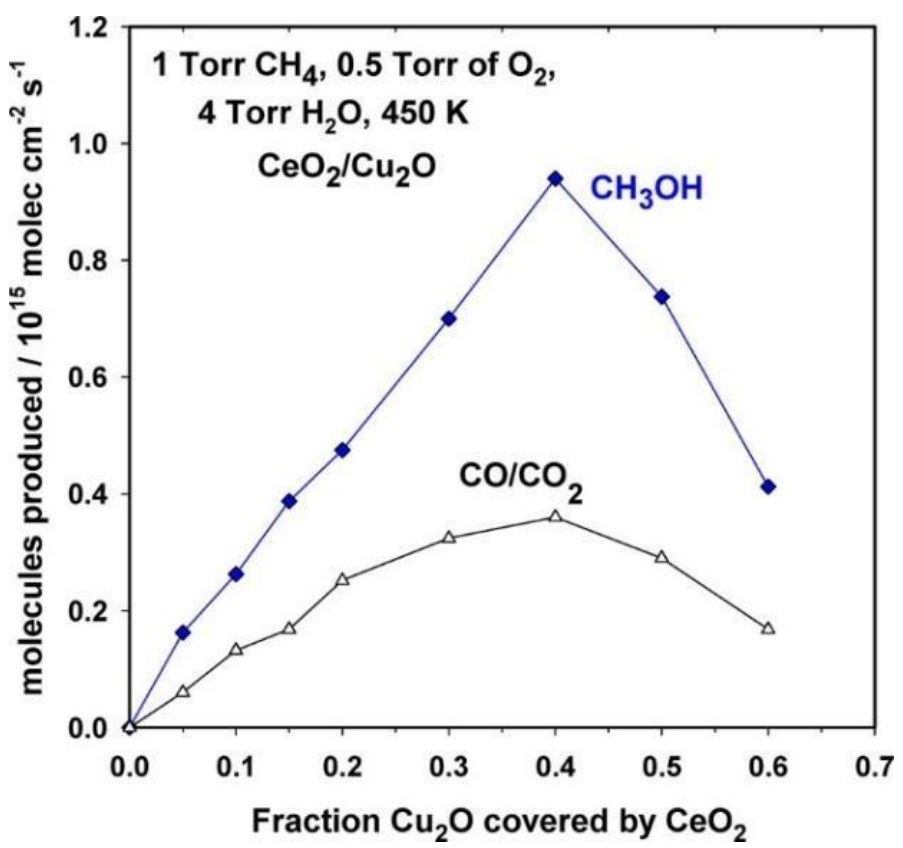

Figure 10. Activity of inverse catalysts: Production of methanol and $\mathrm{CO} / \mathrm{CO}_{2}$ as a function of ceria coverage in a series of $\mathrm{CeO}_{2} / \mathrm{Cu}_{2} \mathrm{O} / \mathrm{Cu}(111)$ catalysts. The samples were exposed to 1 Torr of $\mathrm{CH}_{4}$, 0.5 Torr of $\mathrm{O}_{2}$, and 4 Torr of $\mathrm{H}_{2} \mathrm{O}$ at $450 \mathrm{~K}$ in a batch reactor. Under a water-rich environment and with increasing coverage of ceria on $\mathrm{Cu}_{2} \mathrm{O}$ up to $40 \%$, methanol production rises with $\mathrm{CO}$ and $\mathrm{CO}_{2}$ as secondary products. A ceria coverage higher than $40 \%$ results in two or three layer islands, which are not as active as single layer $\mathrm{O}-\mathrm{Ce}-\mathrm{O}-\mathrm{Cu}$ stacking for methane oxidation [83].

Next to $\mathrm{Cu}-\mathrm{CeO}_{2}, \mathrm{Ni}-\mathrm{CeO}_{2}(111)$ is another suitable catalyst, as the ceria support can modify the electronic properties of nickel by increasing its oxidation state $[117,118]$. It has also been reported for water-assisted methane activation by Lustemberg et al. [119], who co-fed methane, $\mathrm{O}_{2}$, and water to obtain stable catalyst activity, as shown in Figure 11. Co-existence of $\mathrm{O}_{2}$ and water allows $\mathrm{O}_{2}$ to activate methane, at an $\mathrm{O} / \mathrm{Ni} 4 / \mathrm{CeO}_{2}$ surface, and water to lower the activation barrier for the formation of methoxy species (step I). Water produces surface hydroxyl groups on the ceria support, accompanied with the formation of additional $\mathrm{Ce}^{3+}$, thereby lowering the activation energy barrier for methoxy formation from $1.16 \mathrm{eV}$ to $0.31 \mathrm{eV}$, as shown in step II. Moreover, the $\mathrm{OH}$ groups formed produce new adsorbed water molecules by recombining with hydrogen previously abstracted from methane. Despite the water formed, the activation energy barrier for methoxy formation from methyl increases at each further step. 


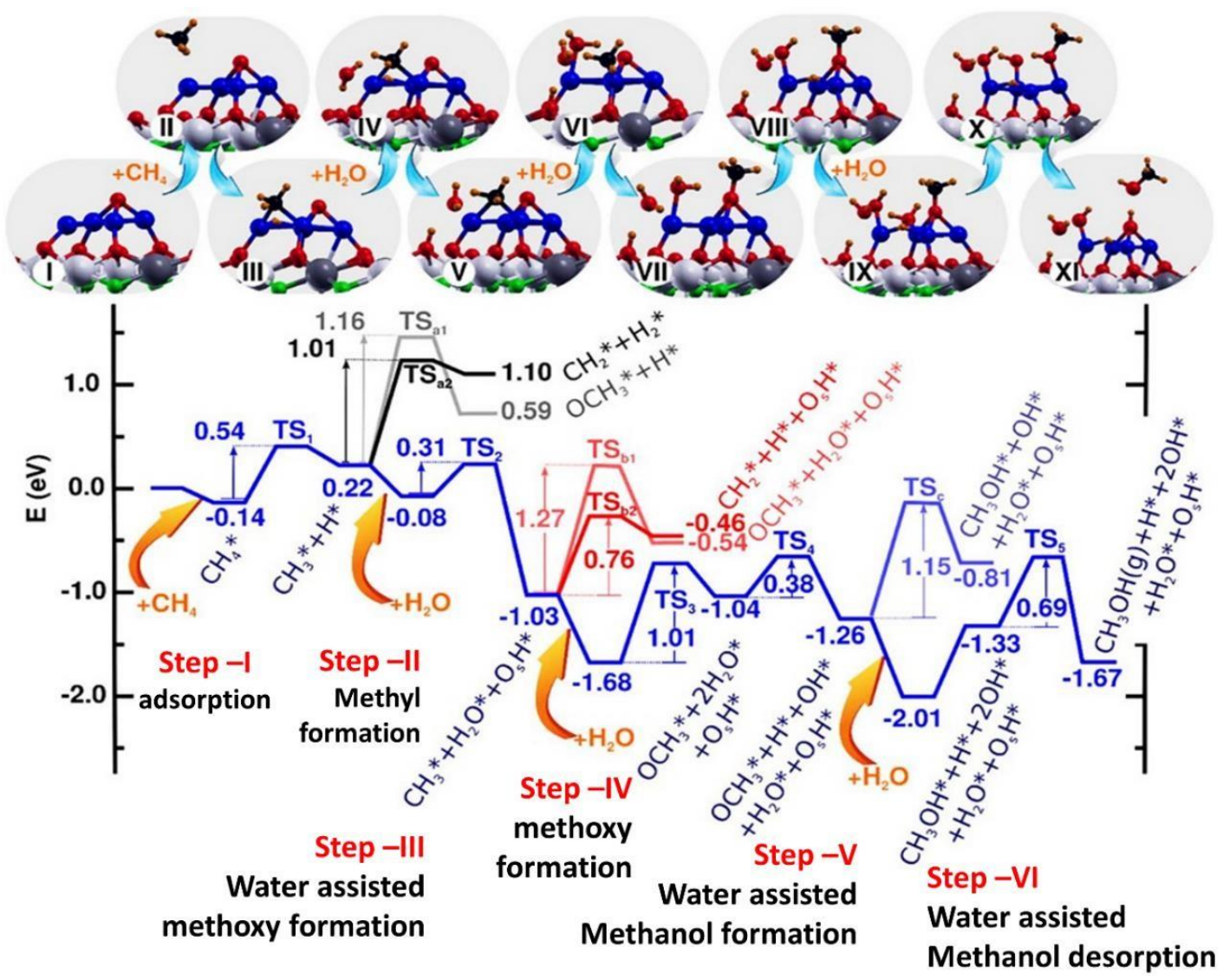

Figure 11. Energy profile for the $\mathrm{CH}_{4}$ to $\mathrm{CH}_{3} \mathrm{OH}$ reaction over an $\mathrm{O} / \mathrm{Ni}_{4} / \mathrm{CeO}_{2}(111)$ surface in presence of $\mathrm{H} 2 \mathrm{O}$ : Energies are referenced to the total energy of $\mathrm{CH}_{4}(\mathrm{~g}), 3 \mathrm{H}_{2} \mathrm{O}(\mathrm{g})$, and the $\mathrm{Ni}_{4} / \mathrm{CeO}_{2}(111)$ surface with chemisorbed oxygen. The side views of the optimized structures are included. Atom color key: $\mathrm{Ni}$ (blue), $\mathrm{Ce}^{3+}$ (gray), $\mathrm{Ce}^{4+}$ (white), surface/subsurface lattice oxygen atoms (red/green), oxygen atoms from chemisorbed species (red), hydrogen (orange), and carbon atoms (black). The principal reaction path is depicted in blue with each step written in red, whereas alternative routes are shown in black, gray, red, and light red, as well as light blue [119].

Hence, water in excess enables us to block all nickel sites that easily dissociate methyl to $\mathrm{C}$ (step IV). Consequently, methanol formation from the methoxy group is also assisted by the $\mathrm{H}$-atom donated by the water adsorbed (step V). Lastly, desorption of methanol occurs via step VI, pointed out in Figure 11, with a $0.69 \mathrm{eV}$ barrier transition state. Hence, excess water helps in the formation and desorption of methanol by providing $\mathrm{H}$ and $\mathrm{OH}$ species to the $\mathrm{Ni}^{-} \mathrm{OCH}_{3}+\mathrm{Ni}-\mathrm{H}$ to yield $\mathrm{Ni}-\mathrm{OH}+\mathrm{Ni}+$ $\mathrm{CH}_{3} \mathrm{OH}(\mathrm{g})$.

Furthermore, ceria as support modifies the electronic properties of nickel by increasing its oxidation state. This modification can be typically important for applications such as electrical sensors, wherein no change in oxidation was reported with effect of temperature, aging, offset, and drift $[117,118]$. Strong metal-support interactions therefore play a crucial role in $\mathrm{O}-\mathrm{H}$ and $\mathrm{C}-\mathrm{H}$ bond dissociation. Hence, excess water not only hinders easy dissociation of methyl to $\mathrm{CH}_{2}+\mathrm{H}$, but also assists in methanol formation and desorption, rendering the reaction more selective for methanol. The methanol selectivity using $\mathrm{Ni}-\mathrm{CeO}_{2}(111)$ with a $4: 1$ ratio of $\mathrm{CH}_{4}: \mathrm{H}_{2} \mathrm{O}$ was reported at $\sim 35 \%$.

The possible crucial role of water and surface hydroxyl species has also been reported by Saeys et al. $[120,121]$ in the activation of CO in Fischer-Tropsch. Using coverage-dependent DFT simulations, De Vrieze et al. [120] reported that the presence of water in the feed converts the alkoxy intermediate to alcohol via proton transfer from either $\mathrm{OH}^{*}$ or $\mathrm{H}_{2} \mathrm{O}^{*}$. Moreover, $\mathrm{ZnO}$ and $\mathrm{CeO}_{x}$, herein, were also reported as facilitators for water activation on a $\mathrm{Cu}$ surface. 
In summary, water could be adequate to achieve slow oxidation of the surface, avoid the formation of strong redox sites, and thereby maintain low oxygen mobility so as to yield a stable reaction intermediate production. However, it should be noted that water alone is not sufficient, because the oxidizing capacity of water cannot balance the reducing power of methane. Further, a feed with only oxygen and methane will result in negligible methanol formation. Hence, it is the intriguing interaction between a strong reducing agent, such as methane, along with the strong oxidant $\mathrm{O}_{2}$ and mild oxidant water, that enables the desired methanol selectivity. Based on the above studies, ceria is a potential material of choice because it can dissociate water and thereby induce the cycle of interaction between formed $\mathrm{OH}, \mathrm{H}$, and $\mathrm{H}_{2} \mathrm{O}$, facilitating methanol production.

Next to ceria, it is well known that metal oxides, such as $\mathrm{Al}_{2} \mathrm{O}_{3}, \mathrm{~V}_{2} \mathrm{O}_{3}, \mathrm{MgO}, \mathrm{Fe}_{3} \mathrm{O}_{4}, \mathrm{TiO}_{2}, \mathrm{CoO}$, $\mathrm{NiO}, \mathrm{ZrO}_{2}$, and $\mathrm{La}_{2} \mathrm{O}_{3}$, as well as perovskites, are active for dissociation of water on their surface, while some of these are also reported for catalytic partial oxidation of methane [122,123]. Such activity is ascribed to the presence of highly uncoordinated defect sites in these oxides. The latter comprise a wide variety of structural arrangements of cations and anions, responsible for a concerted effort via cations binding water and anions abstracting protons. These defect sites or vacancies also account for surface reducibility, which in turn affects catalyst activity and selectivity [124]. On the one hand, low surface reducibility corresponds to high vacancy formation energy, which leads to low C-H activity, but high methanol selectivity. On the other hand, high surface reducibility corresponds to low vacancy formation energy, which entails high activity, but low selectivity. Hence, with metal oxides, which can take multiple oxidation states, it is imperative to obtain an optimal surface reducibility. The desired descriptor for selective oxidation of methane to methanol over metal oxides is then tuning the reactivity of lattice oxygen by optimizing the ratio of co-oxidants next to methane.

\section{Beyond Catalysis: Chemical Looping}

The above discussion on the role of oxygen and water to improve methanol selectivity steers the interest in applying chemical looping (CL) strategies for DMTM. Chemical looping (CL) is a technique applied mainly for oxidation reactions, which involves cyclic reduction and oxidation of a metal oxide that serves as an oxygen carrier. It enables high flexibility to the system via controlled oxidation of the feed by the metal oxide and controlled oxidation parameters for the oxidant, individually. This flexibility makes the process more selective, safer in operation, and allows for complete fuel utilization. In CL, a reaction is divided into sub-reactions, which are linked together by a solid looping material, typically a metal oxide. The reactions can be connected either in separate reactors or as subsequent steps in a single reactor $[125,126]$. CL therefore avoids direct contact of the oxidant and methane, as the stoichiometric oxygen required for the reaction is provided by the metal oxide [127]. Separation of oxidation and the reduction step in CL allows us to bypass dissociation of methyl and over-oxidation of methanol formed, which are the classical challenges in DMTM. There are multiple approaches to perform CL, which comprise of chemical looping combustion (CLC), partial oxidation (CLPO), and selective oxidation (CLSO). Figure 12 shows a typical schematic of chemical looping, which is employed to produce syngas and valuable chemicals from $\mathrm{CO}_{2}$ and/or methane. 


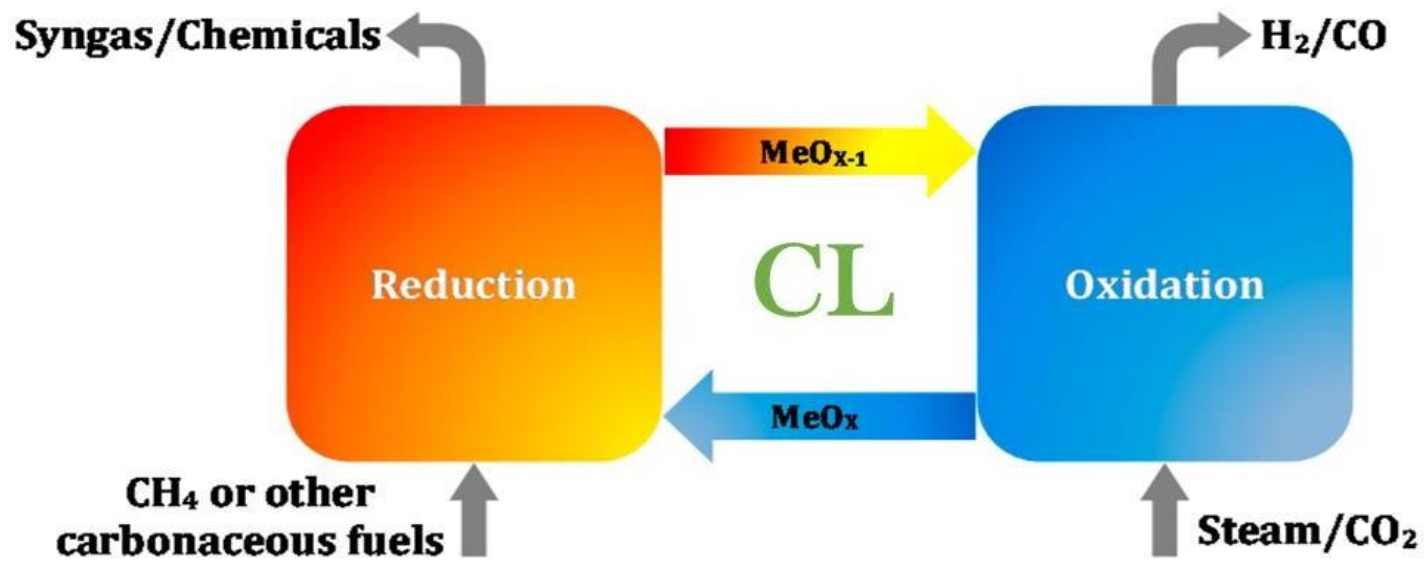

Figure 12. Schematic for a chemical looping process to produce syngas $\left(\mathrm{H}_{2}\right.$ and $\left.\mathrm{CO}\right)$ or chemicals [128].

Chemical looping partial oxidation (CLPO) is particularly suited to generate high quality syngas with tunable $\mathrm{H}_{2}: \mathrm{CO}$ ratio. Perovskites and metal oxides, such as $\mathrm{SrFeO}_{3-\delta} / \mathrm{CaO} \cdot \mathrm{MnO}$ [129], Mo-Fe2O3-CeZrO2 [130], and $\mathrm{LaFeO} 3$ [131], have been reported to yield a $\mathrm{H}_{2}$ :CO ratio of 2. The syngas formed can be further utilized separately to produce methanol. In contrast to CLPO, CLSO applies oxygen carriers with dedicated catalyst sites that enable to produce valuable chemicals [108].

The desired product selectivity in CLSO can be obtained by tuning the nature of surface oxygen species on an oxygen carrier decorated with catalytically active sites [127]. An industrial example of CLSO is the conversion of butane into maleic anhydride (DuPont process), catalyzed by vanadium phosphorous oxide (VPO). In case of DMTM, a high selectivity to methanol is achieved by trapping the reaction intermediate on the surface of the active material, thereby avoiding consecutive oxidation [40].

A modified approach to CLSO was recently reported by Suskevich et al. [22], who applied water as the oxidant for selective oxidation of methane to methanol using a copper exchanged mordenite (Cu-MOR) zeolite, as shown in Figure 13. A direct stepwise mechanism was proposed in this work, wherein each cycle consists of water activation in $\mathrm{Cu}-\mathrm{MOR}$ at $673 \mathrm{~K}$ in a flow of helium, followed by cooling to $473 \mathrm{~K}$ and exposure to methane at 7 bars.

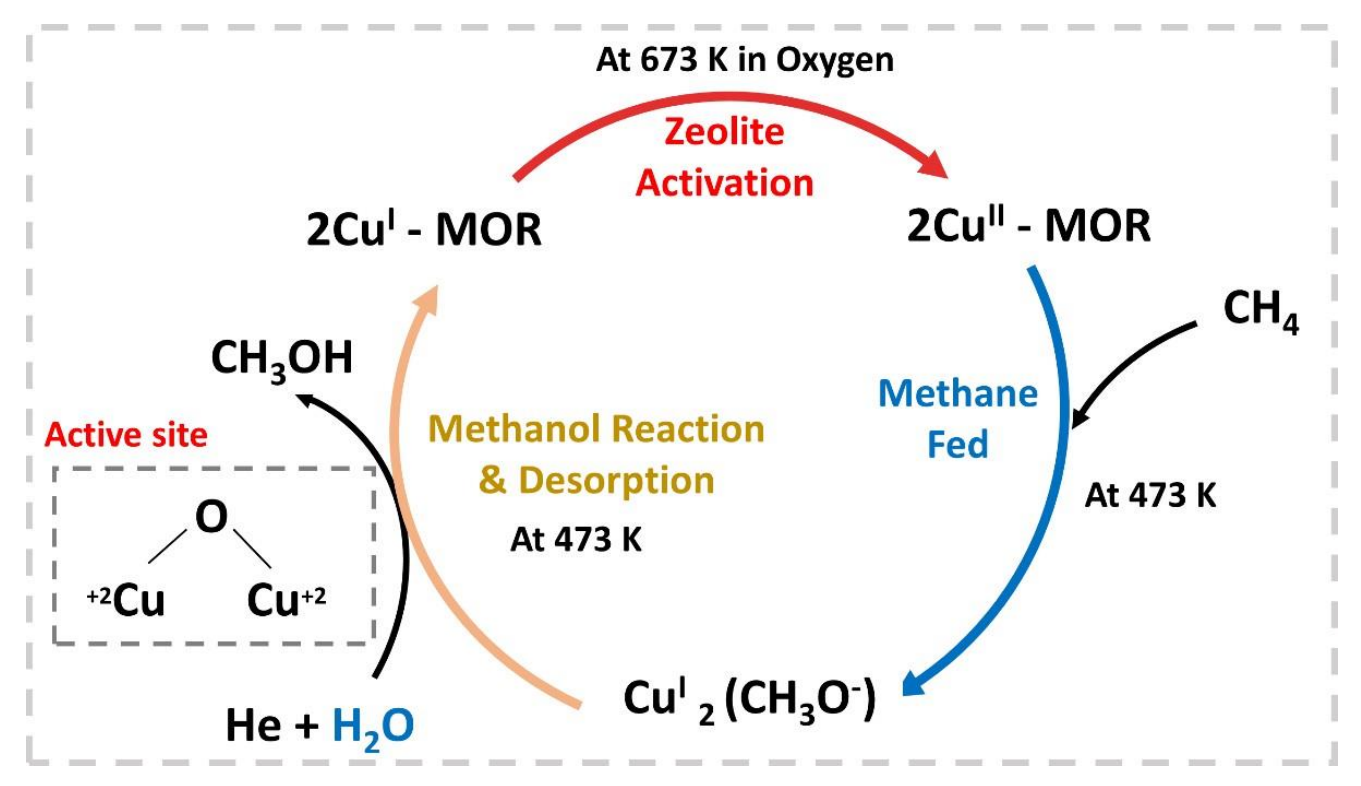

Figure 13. Steps involved in direct conversion of methane to methanol (DMTM) over copper exchanged mordenite (Cu-MOR) [22,40], which requires a cycle of high temperature material activation and low temperature methane activation in order to form methanol using $2 \mathrm{Cu}^{\mathrm{II}}$ as the active site. 
With water as the sole soft oxidant, they observed insertion of oxygen atoms from the water into the $\mathrm{C}-\mathrm{H}$ bond of methane using ${ }^{18} \mathrm{O}$-labeled water experiments, as shown in Figure $14 \mathrm{~A} . \mathrm{CH}_{3}{ }^{18} \mathrm{OH}$ gave a delayed response in the first cycle, indicating only a minor oxygen exchange. However, its signal increased in the second cycle (after methanol desorption and helium treatment), at the expense of the signal from unlabeled methanol, after activation with $\mathrm{H}_{2}{ }^{18} \mathrm{O}$, resulting in more ${ }^{18} \mathrm{O}$ atoms in the active sites of $\mathrm{Cu}-\mathrm{MOR}$.
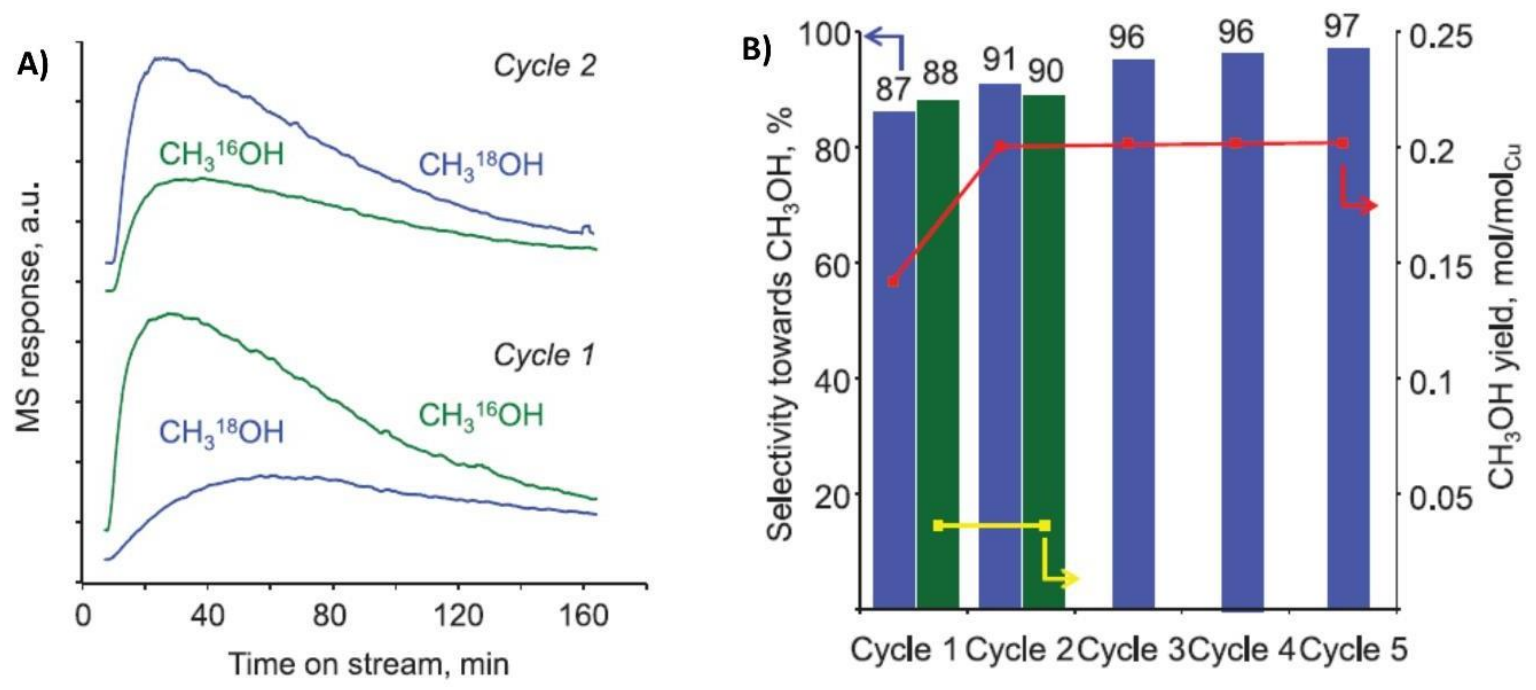

Figure 14. (A) Effect of water on methanol produced over copper-exchanged mordenite zeolites $(\mathrm{Cu}$ MOR): Mass spectral responses for unlabeled $(\mathrm{m} / \mathrm{z}=31)$ and ${ }^{18} \mathrm{O}$-labeled $(\mathrm{m} / \mathrm{z}=33)$ methanol after first and second reactivation with labeled $\mathrm{H}_{2}{ }^{18} \mathrm{O}$, respectively. Insertion of oxygen atoms from water into the carbon-hydrogen $(\mathrm{C}-\mathrm{H})$ bond of methane showed a minor exchange in the first cycle, while becoming dominant in the second [22]. (B) Methanol yield and selectivity across multiple cycles.

Using the cyclic methodology mentioned, Sushkevich et al. [22] reported that the methanol selectivity improved after the admission of water in the first cycle and remained constant during further cycles, as shown in Figure 14B. The presence of water vapor induced reoxidation of the active sites and desorption of methanol from $\mathrm{Cu}-\mathrm{MOR}$ at $473 \mathrm{~K}$ and 1 bar total pressure. The methanol selectivity using this process was reported around $87 \%$ to $97 \%$.

Correlating the $\mathrm{CL}$ redox process to the changing oxidation state of the catalyst further showed that $\mathrm{Cu}-\mathrm{MOR}$ activated at $673 \mathrm{~K}$ mostly contained $\mathrm{Cu}^{\mathrm{II}}$ as the dominant oxidation state, along with a minor fraction of $\mathrm{Cu}^{\mathrm{I}}$ being formed, primarily due to auto-reduction. In presence of methane, the auto-reduction of $\mathrm{Cu}^{\mathrm{II}}$ to $\mathrm{Cu}^{\mathrm{I}}$ causes a loss in catalyst activity. Introduction of water does not induce full conversion of $\mathrm{Cu}^{\mathrm{I}}$ (inactive for methane oxidation) to $\mathrm{Cu}^{\mathrm{II}}$ (active for methane oxidation). Conversion of only a fraction of $\mathrm{Cu}^{\mathrm{I}}$ sites to $\mathrm{Cu}^{\mathrm{II}}$ therefore resulted in less $\mathrm{C}-\mathrm{H}$ bond activation in methane, resulting in a yield of only $0.2 \mathrm{~mol} / \mathrm{mol}_{\mathrm{Cu}}$ at $673 \mathrm{~K}$, in comparison to the maximum theoretical yield of $0.5 \mathrm{~mol} / \mathrm{mol}_{\mathrm{Cu}}$. In contrast to this, an even lower yield of $0.04 \mathrm{~mol} / \mathrm{mol}_{\mathrm{Cu}}$ was reported at $473 \mathrm{~K}$ (that is without any high temperature pre-treatment). This was due to the poisoning effect of water in zeolites at a low temperature. Enhanced catalyst activity was only reported at high methane pressures, ranging between 7 to 25 bars. Moreover, formation of hydrogen was reported as a consequence of water splitting, wherein the $\mathrm{O}$-atoms formed become part of the active $\mathrm{Cu}$ center and react with methane molecules [88].

In recent work, Lange et al. [40] reports that DMTM via chemical looping offers high methanol selectivity, but the methanol production rate of $2 \times 10^{-8} \mathrm{~mol} / \mathrm{g} / \mathrm{s}$ is not sufficient to be industrially promising. In order to become economically viable, an increase in intrinsic material productivity per cycle of the multi-step process is deemed essential [132]. In reference to this, chemical looping of DMTM via $\mathrm{CeO}_{2} / \mathrm{Cu}_{2} \mathrm{O} / \mathrm{Cu}(111)$ serves as a potential candidate for industrial development. As mentioned 
in the previous section, Zuo et al. [83] reported that ceria added to copper oxide is active and selective to methanol formation under a water-rich environment. Moreover, in contrast to $\mathrm{Cu}-\mathrm{MOR}$, no pre-activation of $\mathrm{CeO}_{2} / \mathrm{Cu}_{2} \mathrm{O} / \mathrm{Cu}(111)$ is required at higher temperatures, which makes the process, shown in Figure 15, more simple.

\section{$\mathrm{HO} / \mathrm{CeO}_{2} / \mathrm{Cu}_{2} \mathrm{O} / \mathrm{Cu}(111)$}

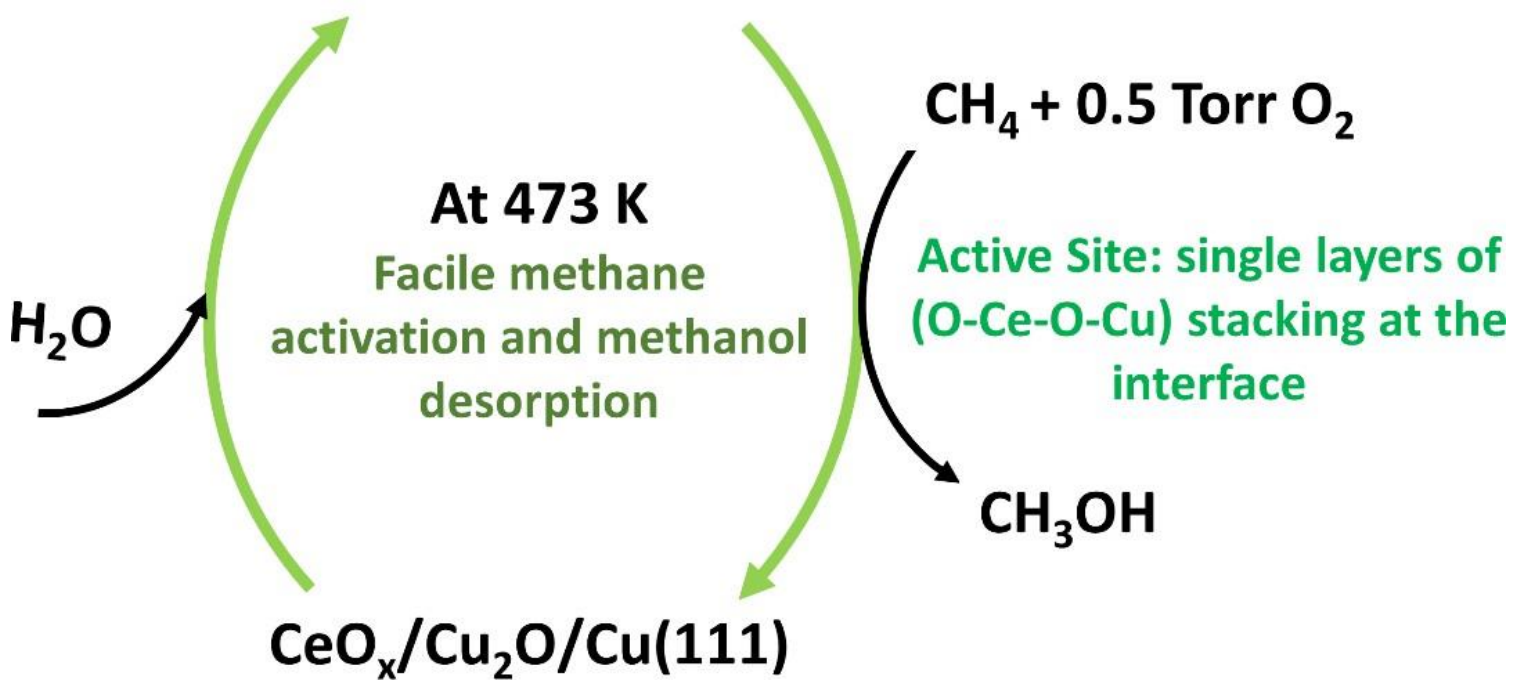

Figure 15. Steps involved in: $\mathrm{CeO}_{2} / \mathrm{Cu}_{2} \mathrm{O} / \mathrm{Cu}$ [75], which can activate methane to form methanol at a single operating temperature in the presence of water using $\mathrm{O}-\mathrm{Ce}-\mathrm{O}-\mathrm{Cu}$ as the active site.

Table 1 shows a comparative activity of catalytic systems reported in literature for selective oxidation of methane to methanol. Comparing these studies, it can be suggested that, irrespective of the material used, whether zeolite systems (Cu-MOR) and/or inverse oxides $\left(\mathrm{CeO}_{2} / \mathrm{Cu}_{2} \mathrm{O} / \mathrm{Cu}\right)$, it is the combined effect of material properties and process parameters that can potentially attain an effective activity, as well as a selectivity trade-off. Moreover, developed interests to employ oxidants, such as water, as discussed above, establish greener chemical processes.

Table 1. Comparative activity of catalytic systems reported in literature for selective oxidation of methane to methanol.

\begin{tabular}{|c|c|c|c|c|c|}
\hline Catalyst & Process & Preparation & $\begin{array}{c}\text { Methanol } \\
\text { Selectivity (\%) }\end{array}$ & $\begin{array}{l}\text { Methanol } \\
\text { Productivity } \\
\text { (mol/g/s) }\end{array}$ & Ref. \\
\hline pMMO & $\begin{array}{c}\text { Biocatalytic } \\
\text { with } \mathrm{O}_{2} \text { as oxidant }\end{array}$ & $\begin{array}{l}\text { Embedding pMMO } \\
\text { in a polymer hydrogel }\end{array}$ & 100 & $10^{-8}$ & [38] \\
\hline $\mathrm{Pt}$ (II) salts & $\begin{array}{l}\text { Liquid phase with } \\
\mathrm{H}_{2} \mathrm{SO}_{4} \text { as oxidant }\end{array}$ & Homogenous phase & 81 & $10^{-7} \mathrm{~mol} / \mathrm{cm}_{3} / \mathrm{s}$ & [44] \\
\hline $\mathrm{Cu}-\mathrm{Fe} /$ silicalite- 1 & $\begin{array}{l}\text { Aqueous hydrogen } \\
\text { peroxide }\end{array}$ & $\begin{array}{l}\text { Mixed homogenous } \\
\text { phase }\end{array}$ & $>90$ & $10^{-7}$ & [45] \\
\hline $\mathrm{AuPdCu} / \mathrm{TiO} 2$ & $\begin{array}{l}\text { Aqueous hydrogen } \\
\text { peroxide }\end{array}$ & $\begin{array}{l}\text { Incipient wetness } \\
\text { impregnation }\end{array}$ & $>80$ & NA & [52] \\
\hline Fe-ZSM5 & $\mathrm{N}_{2} \mathrm{O}$ as oxidant & $\begin{array}{l}\text { Hydrothermal } \\
\text { synthesis }\end{array}$ & $>90$ & NA & {$[54,55]$} \\
\hline Cu-MOR & Water as oxidant & $\begin{array}{l}\text { Conventional ion } \\
\text { exchange }\end{array}$ & $>90$ & $10^{-8}$ & {$[22,40]$} \\
\hline
\end{tabular}




\section{Conclusions}

A dream reaction for chemists across the globe is the direct conversion of methane to methanol. Although the occurrence of this reaction in nature by methane monooxygenase (MMO) is known, its low specific activity makes it unsuitable for industrial application. Catalytic mimicking of MMOs through copper-supported zeolites, such as ZSM-5 and MOR, is reported to activate methane at low temperature and to produce methanol. However, the high acid strength of zeolites results in an increased activation barrier for methanol desorption, which in turn leads to the formation of formaldehyde and, therefore, low methanol yield. Moreover, since it is the oxo species in $\mathrm{Cu}$ or Fe zeolites that activates methane, the cooperative role of $\mathrm{O}$ centers and metal cations become a significant descriptor in the heterogeneous catalysts for oxidation reactions. A similar cooperative activity is prevalent in metal oxides, such as ceria, which are discussed extensively to indicate their activity towards methane activation and methanol selectivity. Metal doping or promotion of ceria facilitates the oxygen vacancy formation, thereby increasing the oxygen mobility. However, higher oxygen mobility favors complete rather than selective methane oxidation. However, the beneficial role of the vacancy defects in metal oxides is limited to methane dissociation and does not promote methanol selectivity. Hence, a better understanding of how active site properties dictate the trade-off in activity and selectivity is essential in order to obtain an optimal design of a DMTM catalyst.

Tuning of lattice oxygen mobility is feasible by controlling the reduction degree of the catalyst. In this context, a surface like that of ceria can dissociate water, which can be used to tune the vacancy defects. The formed $\mathrm{OH}$ species block the metal sites that can readily cause methyl decomposition, thereby hindering complete oxidation of methane. Further, $\mathrm{OH}$ from adsorbed water lowers the activation barrier for methyl to form methoxy species, while $\mathrm{H}$ combines with methoxy to produce methanol. This cycle renders the process more methanol selective. Moreover, the facile water formation and dissociation cycle not only improves methanol formation, but also allows easy methanol desorption. Hence, ceria is an ideal material as it can readily dissociate water, while a combined process methodology, involving methane, along with $\mathrm{O}_{2}$, as well as water, renders DMTM more methanol selective.

Improvement in methanol selectivity can be further achieved by chemical looping approaches. Using $\mathrm{Cu}-\mathrm{MOR}$, such a periodic oxidation-reduction process, with the additional use of a mild oxidant like water, traps the reaction intermediate to improve methanol selectivity. With the current process, more than $90 \%$ methanol selectivity was reported, although still with a low material productivity per cycle of $2 \times 10^{-8} \mathrm{~mol} / \mathrm{g} / \mathrm{s}$. Higher catalyst activity is required to improve the methanol production rate as per the desirable industrial standards.

To conclude, DMTM is suggested to be both material- and process centric, where it's not just a particular species that selectively oxidizes methane to methanol, but it's an intricate interaction between the adsorbed species and the catalyst interface, which controls the activity. An interesting synergy between water and methanol selectivity was highlighted in this study, using catalysts such as $\mathrm{CeO}_{2} / \mathrm{Cu}_{2} \mathrm{O} / \mathrm{Cu}, \mathrm{Ni}-\mathrm{CeO}_{2}(111)$ and $\mathrm{Cu}-\mathrm{MOR}$. Nevertheless, more experimental studies are required to validate these literature results in order to successfully embark DMTM to be viable on an industrial scale.

Author Contributions: R.S. conceptualized the design of manuscript and wrote it; H.P., G.B.M. and V.V.G. contributed in critical revisions of the manuscript. All authors have read and agreed to the published version of the manuscript.

Funding: This work was supported by the "Long Term Structural Methusalem Funding" by the Flemish Government, Grant No. 01M00409

Conflicts of Interest: The authors declare no conflict of interest. 


\section{References}

1. Zakaria, Z.; Kamarudin, S.K. Direct conversion technologies of methane to methanol: An overview. Renew. Sustain. Energy Rev. 2016, 65, 250-261. [CrossRef]

2. Park, D.; Lee, J. Biological conversion of methane to methanol. Korean J. Chem. Eng. 2013, 30, 977-987. [CrossRef]

3. Tomkins, P.; Mansouri, A.; Bozbag, S.E.; Krumeich, F.; Park, M.B.; Alayon, E.M.C.; Ranocchiari, M.; van Bokhoven, J.A. Isothermal Cyclic Conversion of Methane into Methanol over Copper-Exchanged Zeolite at Low Temperature. Angew. Chem. Int. Ed. 2016, 55, 5467-5471. [CrossRef]

4. National Academies of Sciences, Engineering, and Medicine. The Changing Landscape of Hydrocarbon Feedstocks for Chemical Production: Implications for Catalysis: Proceedings of a Workshop; The National Academies Press: Washington, DC, USA, 2016; p. 136.

5. Kennedy, T.F.; Shanks, D. Methanol: Manufacture and Uses. In Monohydric Alcohols; American Chemical Society: Washington, DC, USA, 1981; Volume 159, pp. 19-27.

6. Wickson, E.J. Monohydric Alcohols; American Chemical Society: Washington, DC, USA, 1981; Volume 159, p. 244.

7. Dolan, G. Overview of Global Methanol Fuel Blending, Touching on Benefits of Methanol Blending Methanol Fuel Forum in Trinidad and Tobago in Association with Proman and MI Member MHTL [Online]. 2019. Available online: https://www.methanol.org/wp-content/uploads/2019/02/4.-Greg-Dolan-Overview-ofGlobal-Methanol-Fuel-Blending.pdf. (accessed on 1 December 2018).

8. Sheldon, D. Methanol Production-A Technical History. Johns. Matthey Technol. Rev. 2017, 61, 172-182. [CrossRef]

9. Mittasch, A.P.M.; Winkler, K. Ausfuhrung Organischer Katalysen. Germany Patent DE415686, 24 July 1923.

10. Hansen, J.; Kharecha, P.; Sato, M.; Masson-Delmotte, V.; Ackerman, F.; Beerling, D.J.; Hearty, P.J.; Hoegh-Guldberg, O.; Hsu, S.-L.; Parmesan, C.; et al. Assessing "Dangerous Climate Change": Required Reduction of Carbon Emissions to Protect Young People, Future Generations and Nature. PLoS ONE 2013, 8, e81648. [CrossRef] [PubMed]

11. Hansen, J.; Sato, M.; Ruedy, R.; Lacis, A.; Oinas, V. Global warming in the twenty-first century: An alternative scenario. Proc. Natl. Acad. Sci. USA 2000, 97, 9875-9880. [CrossRef] [PubMed]

12. Lunsford, J.H. Catalytic conversion of methane to more useful chemicals and fuels: A challenge for the 21st century. Catal. Today 2000, 63, 165-174. [CrossRef]

13. Da Silva, M.J. Synthesis of methanol from methane: Challenges and advances on the multi-step (syngas) and one-step routes (DMTM). Fuel Process. Technol. 2016, 145, 42-61. [CrossRef]

14. Methanol Market: Global Industry Trends, Share, Size, Growth, Opportunity and Forecast 2019-2024; IMARC Services Pvt. Ltd.: Uttar Pradesh, India, April 2019; Market Research.com.

15. Usman, M.; Daud, W.M.A.W. Recent advances in the methanol synthesis via methane reforming processes. RSC Adv. 2015, 5, 21945-21972. [CrossRef]

16. Iglesias, I.; Forti, M.; Baronetti, G.; Mariño, F. Zr-enhanced stability of ceria based supports for methane steam reforming at severe reaction conditions. Int. J. Hydrog. Energy 2019, 44, 8121-8132. [CrossRef]

17. Agrafiotis, C.; von Storch, H.; Roeb, M.; Sattler, C. Solar thermal reforming of methane feedstocks for hydrogen and syngas production-A review. Renew. Sustain. Energy Rev. 2014, 29, 656-682. [CrossRef]

18. Penã, M.A.; Gómez, J.P.; Fierro, J.L.G. New catalytic routes for syngas and hydrogen production. Appl. Catal. A 1996, 144, 7-57. [CrossRef]

19. Miguel, C.V.; Soria, M.A.; Mendes, A.; Madeira, L.M. Direct CO2 hydrogenation to methane or methanol from post-combustion exhaust streams-A thermodynamic study. J. Nat. Gas Sci. Eng. 2015, 22, 1-8. [CrossRef]

20. Bozzano, G.; Manenti, F. Efficient methanol synthesis: Perspectives, technologies and optimization strategies. Prog. Energy Combust. Sci. 2016, 56, 71-105. [CrossRef]

21. Sehested, J. Industrial and scientific directions of methanol catalyst development. J. Catal. 2019, 371, 368-375. [CrossRef]

22. Sushkevich, V.L.; Palagin, D.; Ranocchiari, M.; van Bokhoven, J.A. Selective anaerobic oxidation of methane enables direct synthesis of methanol. Science 2017, 356, 523. [CrossRef]

23. Schüth, F. Making more from methane. Science 2019, 363, 1282. [CrossRef] 
24. Mahyuddin, M.H.; Shiota, Y.; Staykov, A.; Yoshizawa, K. Theoretical Overview of Methane Hydroxylation by Copper-Oxygen Species in Enzymatic and Zeolitic Catalysts. Acc. Chem. Res. 2018, 51, 2382-2390. [CrossRef]

25. Hanson, R.S.; Hanson, T.E. Methanotrophic bacteria. Microbiol. Rev. 1996, 60, 439-471. [CrossRef]

26. Hwang, I.Y.; Lee, S.H.; Choi, Y.S.; Park, S.J.; Na, J.G.; Chang, I.S.; Kim, C.; Kim, H.C.; Kim, Y.H.; Lee, J.W.; et al. Biocatalytic conversion of methane to methanol as a key step for development of methane-based biorefineries. J. Microbiol. Biotechnol. 2014, 24, 1597-1605. [CrossRef]

27. Friedle, S.; Reisner, E.; Lippard, S.J. Current challenges of modeling diiron enzyme active sites for dioxygen activation by biomimetic synthetic complexes. Chem. Soc. Rev. 2010, 39, 2768-2779. [CrossRef] [PubMed]

28. Knops-Gerrits, P.-P.H.; Goddard, W.A., III. The structure-activity relationships of methane mono-oxygenase mimics in alkane activation. Catal. Today 2003, 81, 263-286. [CrossRef]

29. Shu, L.; Nesheim, J.C.; Kauffmann, K.; Münck, E.; Lipscomb, J.D.; Que, L. An $\mathrm{Fe}_{2}{ }^{\mathrm{IV}} \mathrm{O}_{2}$ Diamond Core Structure for the Key Intermediate Q of Methane Monooxygenase. Science 1997, 275, 515-518. [CrossRef]

30. Ross, M.O.; Rosenzweig, A.C. A tale of two methane monooxygenases. J. Biol. Inorg. Chem. JBIC 2017, 22, 307-319. [CrossRef] [PubMed]

31. Tinberg, C.E.; Lippard, S.J. Dioxygen Activation in Soluble Methane Monooxygenase. Acc. Chem. Res. 2011, 44, 280-288. [CrossRef] [PubMed]

32. Lee, S.-K.; Lipscomb, J.D. Oxygen Activation Catalyzed by Methane Monooxygenase Hydroxylase Component: Proton Delivery during the O-O Bond Cleavage Steps. Biochemistry 1999, 38, 4423-4432. [CrossRef] [PubMed]

33. Skulan, A.J.; Brunold, T.C.; Baldwin, J.; Saleh, L.; Bollinger, J.M.; Solomon, E.I. Nature of the Peroxo Intermediate of the W48F/D84E Ribonucleotide Reductase Variant: Implications for O2 Activation by Binuclear Non-Heme Iron Enzymes. J. Am. Chem. Soc. 2004, 126, 8842-8855. [CrossRef] [PubMed]

34. Han, W.-G.; Noodleman, L. Structural Model Studies for the Peroxo Intermediate P and the Reaction Pathway from $\mathrm{P} \rightarrow \mathrm{Q}$ of Methane Monooxygenase Using Broken-Symmetry Density Functional Calculations. Inorg. Chem. 2008, 47, 2975-2986. [CrossRef]

35. Balasubramanian, R.; Rosenzweig, A.C. Structural and mechanistic insights into methane oxidation by particulate methane monooxygenase. Acc. Chem. Res. 2007, 40, 573-580. [CrossRef]

36. Ross, M.O.; MacMillan, F.; Wang, J.; Nisthal, A.; Lawton, T.J.; Olafson, B.D.; Mayo, S.L.; Rosenzweig, A.C.; Hoffman, B.M. Particulate methane monooxygenase contains only mononuclear copper centers. Science 2019, 364, 566. [CrossRef]

37. Kamachi, T.; Okura, I. Methanol Biosynthesis Using Methanotrophs. In Methane Biocatalysis: Paving the Way to Sustainability; Kalyuzhnaya, M.G., Xing, X.-H., Eds.; Springer International Publishing: Cham, Switzerland, 2018; pp. 169-182.

38. Blanchette, C.D.; Knipe, J.M.; Stolaroff, J.K.; DeOtte, J.R.; Oakdale, J.S.; Maiti, A.; Lenhardt, J.M.; Sirajuddin, S.; Rosenzweig, A.C.; Baker, S.E. Printable enzyme- embedded materials for methane to methanol conversion. Nat. Commun. 2016, 7, 11900. [CrossRef] [PubMed]

39. Sirajuddin, S.; Barupala, D.; Helling, S.; Marcus, K.; Stemmler, T.L.; Rosenzweig, A.C. Effects of zinc on particulate methane monooxygenase activity and structure. J. Biol. Chem. 2014, 289, 21782-21794. [CrossRef]

40. Lange, J.-P.; Sushkevich, V.L.; Knorpp, A.J.; van Bokhoven, J.A. Methane-to- Methanol via Chemical Looping: Economic Potential and Guidance for Future Research. Ind. Eng. Chem. Res. 2019, 58, 8674-8680. [CrossRef]

41. Szécsényi, Á.; Khramenkova, E.; Chernyshov, I.Y.; Li, G.; Gascon, J.; Pidko, E.A. Breaking Linear Scaling Relationships with Secondary Interactions in Confined Space: A Case Study of Methane Oxidation by Fe/ZSM-5 Zeolite. ACS Catal. 2019, 9, 9276-9284. [CrossRef]

42. Prikhod'ko, R.V.; Astrelin, I.M.; Sychev, M.V.; Hensen, E.J.M. Influence of preparation procedure on the surface chemistry and catalytic characteristics of FeZSM-5 zeolite in selective oxidation of benzene to phenol. Russ. J. Appl. Chem. 2006, 79, 1115-1121. [CrossRef]

43. Periana, R.A.; Taube, D.J.; Evitt, E.R.; Loffler, D.G.; Wentrcek, P.R.; Voss, G.; Masuda, T. A mercury-catalyzed, high-yield system for the oxidation of methane to methanol. Science 1993, 259, 340-343. [CrossRef]

44. Periana, R.A.; Taube, D.J.; Gamble, S.; Taube, H.; Satoh, T.; Fujii, H. Platinum catalysts for the high-yield oxidation of methane to a methanol derivative. Science 1998, 280, 560-564. [CrossRef] 
45. Hammond, C.; Forde, M.M.; Ab Rahim, M.H.; Thetford, A.; He, Q.; Jenkins, R.L.; Dimitratos, N.; Lopez-Sanchez, J.A.; Dummer, N.F.; Murphy, D.M.; et al. Direct catalytic conversion of methane to methanol in an aqueous medium by using copper-promoted Fe-ZSM-5. Angew. Chem. Int. Ed. 2012, 51, 5129-5133. [CrossRef]

46. Hammond, C.; Dimitratos, N.; Lopez-Sanchez, J.A.; Jenkins, R.L.; Whiting, G.; Kondrat, S.A.; ab Rahim, M.H.; Forde, M.M.; Thetford, A.; Hagen, H.; et al. Aqueous-Phase Methane Oxidation over Fe-MFI Zeolites; Promotion through Isomorphous Framework Substitution. ACS Catal. 2013, 3, 1835-1844. [CrossRef]

47. Forde, M.M.; Armstrong, R.D.; McVicker, R.; Wells, P.P.; Dimitratos, N.; He, Q.; Lu, L.; Jenkins, R.L.; Hammond, C.; Lopez-Sanchez, J.A.; et al. Light alkane oxidation using catalysts prepared by chemical vapour impregnation: Tuning alcohol selectivity through catalyst pre-treatment. Chem. Sci. 2014, 5, 3603-3616. [CrossRef]

48. Hammond, C.; Dimitratos, N.; Jenkins, R.L.; Lopez-Sanchez, J.A.; Kondrat, S.A.; Hasbi ab Rahim, M.; Forde, M.M.; Thetford, A.; Taylor, S.H.; Hagen, H.; et al. Elucidation and Evolution of the Active Component within Cu/Fe/ZSM-5 for Catalytic Methane Oxidation: From Synthesis to Catalysis. ACS Catal. 2013, 785, 689-699. [CrossRef]

49. Agarwal, N.; Freakley, S.J.; McVicker, R.U.; Althahban, S.M.; Dimitratos, N.; He, Q.; Morgan, D.J.; Jenkins, R.L.; Willock, D.J.; Taylor, S.H.; et al. Aqueous Au-Pd colloids catalyze selective $\mathrm{CH}_{4}$ oxidation to $\mathrm{CH}_{3} \mathrm{OH}$ with $\mathrm{O}_{2}$ under mild conditions. Science 2017, 358, 223-227. [CrossRef] [PubMed]

50. Ab Rahim, M.H.; Forde, M.M.; Jenkins, R.L.; Hammond, C.; He, Q.; Dimitratos, N.; Lopez- Sanchez, J.A.; Carley, A.F.; Taylor, S.H.; Willock, D.J.; et al. Oxidation of Methane to Methanol with Hydrogen Peroxide Using Supported Gold-Palladium Alloy Nanoparticles. Angew. Chem. Int. Ed. 2013, 52, 1280-1284. [CrossRef] [PubMed]

51. Ab Rahim, M.H.; Forde, M.M.; Hammond, C.; Jenkins, R.L.; Dimitratos, N.; Lopez-Sanchez, J.A.; Carley, A.F.; Taylor, S.H.; Willock, D.J.; Hutchings, G.J. Systematic Study of the Oxidation of Methane Using Supported Gold Palladium Nanoparticles Under Mild Aqueous Conditions. Top. Catal. 2013, 56, 1843-1857. [CrossRef]

52. Ab Rahim, M.H.; Armstrong, R.D.; Hammond, C.; Dimitratos, N.; Freakley, S.J.; Forde, M.M.; Morgan, D.J.; Lalev, G.; Jenkins, R.L.; Lopez-Sanchez, J.A.; et al. Low temperature selective oxidation of methane to methanol using titania supported gold palladium copper catalysts. Catal. Sci. Technol. 2016, 6, 3410-3418. [CrossRef]

53. Pannov, G.I.; Sobolev, V.I.; Kharitonov, A.S. The role of iron in N2O decomposition on ZSM-5 zeolite and reactivity of the surface oxygen formed. J. Mol. Catal. 1990, 61, 85-97. [CrossRef]

54. Panov, G.I.; Sobolev, V.I.; Dubkov, K.A.; Parmon, V.N.; Ovanesyan, N.S.; Shilov, A.E.; Shteinman, A.A. Iron complexes in zeolites as a new model of methane monooxygenase. React. Kinet. Catal. Lett. 1997, 61, 251-258. [CrossRef]

55. Starokon, E.V.; Parfenov, M.V.; Arzumanov, S.S.; Pirutko, L.V.; Stepanov, A.G.; Panov, G.I. Oxidation of methane to methanol on the surface of FeZSM-5 zeolite. J. Catal. 2013, 300, 47-54. [CrossRef]

56. Starokon, E.V.; Parfenov, M.V.; Pirutko, L.V.; Abornev, S.I.; Panov, G.I. Room-Temperature Oxidation of Methane by $\alpha$-Oxygen and Extraction of Products from the FeZSM-5 Surface. J. Phys. Chem. C 2011, 115, 2155-2161. [CrossRef]

57. Malykhin, S. Hydrogen abstraction reactions of the $[\mathrm{FeO}] 2+$ moiety: The role of the electronic state. Chem. Phys. Lett. 2015, 622, 69-74. [CrossRef]

58. Rosa, A.; Ricciardi, G.; Jan Baerends, E. Is $[\mathrm{FeO}](2+)$ the active center also in iron containing zeolites? A density functional theory study of methane hydroxylation catalysis by Fe-ZSM-5 zeolite. Inorg. Chem. 2010, 49, 3866-3880. [CrossRef] [PubMed]

59. Zhidomirov, G.; Shubin, A.; Larin, A.; Malykhin, S.; Rybakov, A. Molecular Models of the Stabilization of Bivalent Metal Cations in Zeolite Catalysts; Springer: Dordrecht, 2011; pp. 579-643.

60. Woertink, J.S.; Smeets, P.J.; Groothaert, M.H.; Vance, M.A.; Sels, B.F.; Schoonheydt, R.A.; Solomon, E.I. A [Cu2O]2+ core in Cu-ZSM-5, the active site in the oxidation of methane to methanol. Proc. Natl. Acad. Sci. USA 2009, 106, 18908-18913. [CrossRef] [PubMed]

61. Grundner, S.; Markovits, M.A.C.; Li, G.; Tromp, M.; Pidko, E.A.; Hensen, E.J.M.; Jentys, A.; Sanchez-Sanchez, M.; Lercher, J.A. Single-site trinuclear copper oxygen clusters in mordenite for selective conversion of methane to methanol. Nat. Commun. 2015, 6, 7546. [CrossRef] [PubMed] 
62. Smeets, P.J.; Groothaert, M.H.; Schoonheydt, R.A. Cu based zeolites: A UV-vis study of the active site in the selective methane oxidation at low temperatures. Catal. Today 2005, 110, 303-309. [CrossRef]

63. Groothaert, M.H.; Lievens, K.; van Bokhoven, J.A.; Battiston, A.A.; Weckhuysen, B.M.; Pierloot, K.; Schoonheydt, R.A. Bis( $\mu$-oxo)dicopper as Key Intermediate in the Catalytic Decomposition of Nitric Oxide. Chemphyschem 2003, 4, 626-630. [CrossRef]

64. Groothaert, M.H.; van Bokhoven, J.A.; Battiston, A.A.; Weckhuysen, B.M.; Schoonheydt, R.A. Bis( $\mu$-oxo)dicopper in Cu-ZSM-5 and Its Role in the Decomposition of NO: A Combined in Situ XAFS, UV-Vis-Near-IR, and Kinetic Study. J. Am. Chem. Soc. 2003, 125, 7629-7640. [CrossRef]

65. Li, G.; Vassilev, P.; Sanchez-Sanchez, M.; Lercher, J.A.; Hensen, E.J.M.; Pidko, E.A. Stability and reactivity of copper oxo-clusters in ZSM-5 zeolite for selective methane oxidation to methanol. J. Catal. 2016, 338, 305-312. [CrossRef]

66. Mahyuddin, M.H.; Staykov, A.; Shiota, Y.; Miyanishi, M.; Yoshizawa, K. Roles of Zeolite Confinement and $\mathrm{Cu}-\mathrm{O}-\mathrm{Cu}$ Angle on the Direct Conversion of Methane to Methanol by [Cu2( $\mu-\mathrm{O})] 2+-$ Exchanged AEI, CHA, AFX, and MFI Zeolites. ACS Catal. 2017, 7, 3741-3751. [CrossRef]

67. Chan, S.I.; Wang, V.C.C.; Lai, J.C.H.; Yu, S.S.F.; Chen, P.P.Y.; Chen, K.H.C.; Chen, C.-L.; Chan, M.K. Redox Potentiometry Studies of Particulate Methane Monooxygenase: Support for a Trinuclear Copper Cluster Active Site. Angew. Chem. Int. Ed. 2007, 46, 1992-1994. [CrossRef]

68. Mahyuddin, M.H.; Staykov, A.; Shiota, Y.; Yoshizawa, K. Direct Conversion of Methane to Methanol by Metal-Exchanged ZSM-5 Zeolite (Metal = Fe, Co, Ni, Cu). ACS Catal. 2016, 6, 8321-8331. [CrossRef]

69. Hunger, B.; Matysik, S.; Heuchel, M.; Einicke, W.-D. Adsorption of Methanol on ZSM-5 Zeolites. Langmuir 1997, 13, 6249-6254. [CrossRef]

70. Mullins, D.R.; Robbins, M.D.; Zhou, J. Adsorption and reaction of methanol on thin-film cerium oxide. Surf. Sci. 2006, 600, 1547-1558. [CrossRef]

71. Narsimhan, K.; Iyoki, K.; Dinh, K.; Román-Leshkov, Y. Catalytic Oxidation of Methane into Methanol over Copper-Exchanged Zeolites with Oxygen at Low Temperature. ACS Cent. Sci. 2016, 2, 424-429. [CrossRef] [PubMed]

72. Groothaert, M.H.; Smeets, P.J.; Sels, B.F.; Jacobs, P.A.; Schoonheydt, R.A. Selective Oxidation of Methane by the Bis( $\mu$-oxo)dicopper Core Stabilized on ZSM-5 and Mordenite Zeolites. J. Am. Chem. Soc. 2005, 127, 1394-1395. [CrossRef] [PubMed]

73. Dandu, N.K.; Adeyiga, O.; Panthi, D.; Bird, S.A.; Odoh, S.O. Performance of density functional theory for describing hetero-metallic active-site motifs for methane-to- methanol conversion in metal-exchanged zeolites. J. Comput. Chem. 2018, 39, 2667-2678. [CrossRef] [PubMed]

74. Ison, A.; Gorte, R.J. The adsorption of methanol and water on H-ZSM-5. J. Catal. 1984, 89, 150-158. [CrossRef]

75. Omojola, T.; Cherkasov, N.; McNab, A.I.; Lukyanov, D.B.; Anderson, J.A.; Rebrov, E.V.; van Veen, A.C. Mechanistic Insights into the Desorption of Methanol and Dimethyl Ether Over ZSM-5 Catalysts. Catal. Lett. 2018, 148, 474-488. [CrossRef]

76. Zhang, X.; He, D.; Zhang, Q.; Xu, B.; Zhu, Q. Comparative studies on direct conversion of methane to methanol/formaldehyde over La-Co-O and $\mathrm{ZrO} 2$ supported molybdenum oxide catalysts. Top. Catal. 2005, 32, 215-223. [CrossRef]

77. Fu, G.; Xu, X.; Lu, X.; Wan, H. Mechanisms of Methane Activation and Transformation on Molybdenum Oxide Based Catalysts. J. Am. Chem. Soc. 2005, 127, 3989-3996. [CrossRef]

78. Rocha, R.S.; Reis, R.M.; Lanza, M.R.V.; Bertazzoli, R. Electrosynthesis of methanol from methane: The role of $\mathrm{V} 2 \mathrm{O} 5$ in the reaction selectivity for methanol of a $\mathrm{TiO} 2 / \mathrm{RuO} 2 / \mathrm{V} 2 \mathrm{O} 5$ gas diffusion electrode. Electrochim. Acta 2013, 87, 606-610. [CrossRef]

79. Wachs, I.E.; Routray, K. Catalysis Science of Bulk Mixed Oxides. ACS Catal. 2012, 2, 1235-1246. [CrossRef]

80. Wang, X.M.N.M.; Nilsson, J.; Carlson, S.; Gustafson, J.; Skoglundh, M.; Carlsson, P.-A. Copper-Modified Zeolites and Silica for Conversion of Methane to Methanol. Catalysts 2018, 8, 545. [CrossRef]

81. Aoki, K.; Ohmae, M.; Nanba, T.; Takeishi, K.; Azuma, N.; Ueno, A.; Ohfune, H.; Hayashi, H.; Udagawa, Y. Direct conversion of methane into methanol over $\mathrm{MoO} 3 / \mathrm{SiO} 2$ catalyst in an excess amount of water vapor. Catal. Today 1998, 45, 29-33. [CrossRef]

82. Zhang, F.; Yao, S.; Liu, Z.; Gutiérrez, R.A.; Vovchok, D.; Cen, J.; Xu, W.; Ramírez, P.J.; Kim, T.; Senanayake, S.D.; et al. Reaction of Methane with $\mathrm{MOx} / \mathrm{CeO} 2(\mathrm{M}=\mathrm{Fe}, \mathrm{Ni}$, and $\mathrm{Cu})$ Catalysts: In Situ Studies with Time-Resolved X-ray Diffraction. J. Phys. Chem. C 2018, 122, 28739-28747. [CrossRef] 
83. Zuo, Z.; Ramírez, P.J.; Senanayake, S.D.; Liu, P.; Rodriguez, J.A. Low-Temperature Conversion of Methane to Methanol on $\mathrm{CeOx} / \mathrm{Cu} 2 \mathrm{O}$ Catalysts: Water Controlled Activation of the C-H Bond. J. Am. Chem. Soc. 2016, 138, 13810-13813. [CrossRef]

84. Nibbelke, R.H.; Scheerova, J.; Decroon, M.H.J.M.; Marin, G.B. The Oxidative Coupling of Methane over MgO-Based Catalysts: A Steady-State Isotope Transient Kinetic Analysis. J. Catal. 1995, 156, 106-119. [CrossRef]

85. Haber, J.; Grzybowska, B. Mechanism of the oxidation of olefins on mixed oxide catalysts. J. Catal. 1973, 28, 489-492. [CrossRef]

86. Haber, J.; Janas, J.; Schiavello, M.; Tilley, R.J.D. Tungsten oxides as catalysts in selective oxidation. J. Catal. 1983, 82, 395-403. [CrossRef]

87. Védrine, J.C.; Fechete, I. Heterogeneous partial oxidation catalysis on metal oxides. Comptes Rendus Chim. 2016, 19, 1203-1225. [CrossRef]

88. Pacchioni, G. Oxygen Vacancy: The Invisible Agent on Oxide Surfaces. Chemphyschem 2003, 4, $1041-1047$. [CrossRef]

89. Grootendorst, E.J.; Verbeek, Y.; Ponec, V. The Role of the Mars and Van Krevelen Mechanism in the Selective Oxidation of Nitrosobenzene and the Deoxygenation of Nitrobenzene on Oxidic Catalysts. J. Catal. 1995, 157, 706-712. [CrossRef]

90. Liang, Z.; Li, T.; Kim, M.; Asthagiri, A.; Weaver, J.F. Low-temperature activation of methane on the $\operatorname{IrO}_{2}(110)$ surface. Science 2017, 356, 299. [PubMed]

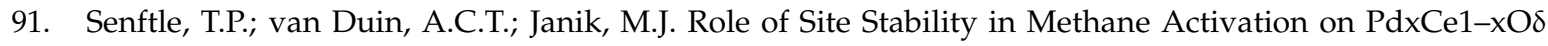
Surfaces. ACS Catal. 2015, 5, 6187-6199. [CrossRef]

92. Mayernick, A.D.; Janik, M.J. Methane Activation and Oxygen Vacancy Formation over CeO2 and Zr, Pd Substituted CeO2 Surfaces. J. Phys. Chem. C 2008, 112, 14955-14964. [CrossRef]

93. Arnold, E.W.; Sundaresan, S. The role of lattice oxygen in the dynamic behavior of oxide catalysts. Chem. Eng. Commun. 1987, 58, 213-230. [CrossRef]

94. Wang, L.; Yu, Y.; He, H.; Zhang, Y.; Qin, X.; Wang, B. Oxygen vacancy clusters essential for the catalytic activity of $\mathrm{CeO} 2$ nanocubes for o-xylene oxidation. Sci. Rep. 2017, 7, 12845. [CrossRef]

95. Trovarelli, A. Catalytic Properties of Ceria and CeO2-Containing Materials. Catal. Rev. 1996, 38, 439-520. [CrossRef]

96. Nolan, M.; Parker, S.C.; Watson, G.W. The electronic structure of oxygen vacancy defects at the low index surfaces of ceria. Surf. Sci. 2005, 595, 223-232. [CrossRef]

97. Sayle, T.X.T.; Parker, S.C.; Catlow, C.R.A. Surface oxygen vacancy formation on $\mathrm{CeO} 2$ and its role in the oxidation of carbon monoxide. J. Chem. Soc. Chem. Commun. 1992, 14, 977-978. [CrossRef]

98. Mullins, D.R. The surface chemistry of cerium oxide. Surf. Sci. Rep. 2015, 70, 42-85. [CrossRef]

99. Meledina, M.; Turner, S.; Galvita, V.V.; Poelman, H.; Marin, G.B.; Van Tendeloo, G. Local environment of Fe dopants in nanoscale $\mathrm{Fe}$ : $\mathrm{CeO} 2-x$ oxygen storage material. Nanoscale 2015, 7, 3196-3204. [CrossRef] [PubMed]

100. Tian, D.; Li, K.; Wei, Y.; Zhu, X.; Zeng, C.; Cheng, X.; Zheng, Y.; Wang, H. DFT insights into oxygen vacancy formation and $\mathrm{CH} 4$ activation over $\mathrm{CeO} 2$ surfaces modified by transition metals (Fe, Co and Ni). Phys. Chem. Chem. Phys. 2018, 20, 11912-11929. [CrossRef] [PubMed]

101. Ruiz Puigdollers, A.; Schlexer, P.; Tosoni, S.; Pacchioni, G. Increasing Oxide Reducibility: The Role of Metal/Oxide Interfaces in the Formation of Oxygen Vacancies. ACS Catal. 2017, 7, 6493-6513. [CrossRef]

102. Menon, U.; Poelman, H.; Bliznuk, V.; Galvita, V.V.; Poelman, D.; Marin, G.B. Nature of the active sites for the total oxidation of toluene by CuOCeO2/Al2O3. J. Catal. 2012, 295, 91-103. [CrossRef]

103. Pacchioni, G. Electronic interactions and charge transfers of metal atoms and clusters on oxide surfaces. Phys. Chem. Chem. Phys. 2013, 15, 1737-1757. [CrossRef] [PubMed]

104. Kashfi-Sadabad, R.; Yazdani, S.; Huan, T.D.; Cai, Z.; Pettes, M.T. Role of Oxygen Vacancy Defects in the Electrocatalytic Activity of Substoichiometric Molybdenum Oxide. J. Phys. Chem. C 2018, 122, 18212-18222. [CrossRef]

105. Singha, R.K.; Tsuji, Y.; Mahyuddin, M.H.; Yoshizawa, K. Methane Activation at the Metal-Support Interface of Ni4-CeO2(111) Catalyst: A Theoretical Study. J. Phys. Chem. C 2019, 123, 9788-9798. [CrossRef] 
106. Liu, Z.; Lustemberg, P.; Gutierrez, R.A.; Carey, J.J.; Palomino, R.M.; Vorokhta, M.; Grinter, D.C.; Ramirez, P.J.; Matolin, V.; Nolan, M.; et al. In Situ Investigation of Methane Dry Reforming on Metal/Ceria(111) Surfaces: Metal-Support Interactions and C-H Bond Activation at Low Temperature. Angew. Chem. Int. Ed. 2017, 56, 13041-13046. [CrossRef]

107. Sadykov, V.A.; Kuznetsova, T.G.; Alikina, G.M.; Frolova, Y.V.; Lukashevich, A.I.; Potapova, Y.V.; Muzykantov, V.S.; Rogov, V.A.; Kriventsov, V.V.; Kochubei, D.I.; et al. Ceria- based fluorite-like oxide solid solutions as catalysts of methane selective oxidation into syngas by the lattice oxygen: Synthesis, characterization and performance. Catal. Today 2004, 93-95, 45-53. [CrossRef]

108. Zeng, L.; Cheng, Z.; Fan, J.A.; Fan, L.-S.; Gong, J. Metal oxide redox chemistry for chemical looping processes. Nat. Rev. Chem. 2018, 2, 349-364. [CrossRef]

109. Menon, U.; Galvita, V.V.; Marin, G.B. Reaction network for the total oxidation of toluene over CuO-CeO2/Al2O3. J. Catal. 2011, 283, 1-9. [CrossRef]

110. Rodríguez, J.A.; Hrbek, J. Inverse oxide/metal catalysts: A versatile approach for activity tests and mechanistic studies. Surf. Sci. 2010, 604, 241-244. [CrossRef]

111. Rodriguez, J.A.; Graciani, J.; Evans, J.; Park, J.B.; Yang, F.; Stacchiola, D.; Senanayake, S.D.; Ma, S.; Pérez, M.; Liu, P.; et al. Water-Gas Shift Reaction on a Highly Active Inverse CeOx/Cu(111) Catalyst: Unique Role of Ceria Nanoparticles. Angew. Chem. Int. Ed. 2009, 48, 8047-8050. [CrossRef]

112. Senanayake, S.D.; Stacchiola, D.; Rodriguez, J.A. Unique Properties of Ceria Nanoparticles Supported on Metals: Novel Inverse Ceria/Copper Catalysts for CO Oxidation and the Water-Gas Shift Reaction. Acc. Chem. Res. 2013, 46, 1702-1711. [CrossRef] [PubMed]

113. Loschen, C.; Migani, A.; Bromley, S.T.; Illas, F.; Neyman, K.M. Density functional studies of model cerium oxide nanoparticles. Phys. Chem. Chem. Phys. 2008, 10, 5730-5738. [CrossRef] [PubMed]

114. Vayssilov, G.N.; Mihaylov, M.; Petkov, P.S.; Hadjiivanov, K.I.; Neyman, K.M. Reassignment of the Vibrational Spectra of Carbonates, Formates, and Related Surface Species on Ceria: A Combined Density Functional and Infrared Spectroscopy Investigation. J. Phys. Chem. C 2011, 115, 23435-23454. [CrossRef]

115. Paier, J.; Penschke, C.; Sauer, J. Oxygen Defects and Surface Chemistry of Ceria: Quantum Chemical Studies Compared to Experiment. Chem. Rev. 2013, 113, 3949-3985. [CrossRef]

116. Yang, Z.; Woo, T.K.; Baudin, M.; Hermansson, K. Atomic and electronic structure of unreduced and reduced CeO2 surfaces: A first-principles study. J. Chem. Phys. 2004, 120, 7741-7749. [CrossRef]

117. Matko, V.; Milanović, M. Temperature-compensated capacitance-frequency converter with high resolution. Sens. Actuators A Phys. 2014, 220, 262-269. [CrossRef]

118. Zheng, X.; Fan, R.; Li, C.; Yang, X.; Li, H.; Lin, J.; Zhou, X.; Lv, R. A fast-response and highly linear humidity sensor based on quartz crystal microbalance. Sens. Actuators B Chem. 2019, 283, 659-665. [CrossRef]

119. Lustemberg, P.G.; Palomino, R.M.; Gutiérrez, R.A.; Grinter, D.C.; Vorokhta, M.; Liu, Z.; Ramírez, P.J.; Matolín, V.; Ganduglia-Pirovano, M.V.; Senanayake, S.D.; et al. Direct Conversion of Methane to Methanol on Ni-Ceria Surfaces: Metal-Support Interactions and Water-Enabled Catalytic Conversion by Site Blocking. J. Am. Chem. Soc. 2018, 140, 7681-7687. [CrossRef]

120. De Vrieze, J.E.; Thybaut, J.W.; Saeys, M. Role of Surface Hydroxyl Species in Copper-Catalyzed Hydrogenation of Ketones. ACS Catal. 2018, 8, 7539-7548. [CrossRef]

121. Gunasooriya, G.T.K.K.; van Bavel, A.P.; Kuipers, H.P.C.E.; Saeys, M. Key Role of Surface Hydroxyl Groups in C-O Activation during Fischer-Tropsch Synthesis. ACS Catal. 2016, 6, 3660-3664. [CrossRef]

122. Henderson, M.A. The interaction of water with solid surfaces: Fundamental aspects revisited. Surf. Sci. Rep. 2002, 46, 1-308. [CrossRef]

123. Kauppi, E.I.; Honkala, K.; Krause, A.O.I.; Kanervo, J.M.; Lefferts, L. ZrO2 Acting as a Redox Catalyst. Top. Catal. 2016, 59, 823-832. [CrossRef]

124. Kumar, G.; Lau, S.L.J.; Krcha, M.D.; Janik, M.J. Correlation of Methane Activation and Oxide Catalyst Reducibility and Its Implications for Oxidative Coupling. ACS Catal. 2016, 6, 1812-1821. [CrossRef]

125. Galvita, V.V.; Poelman, H.; Bliznuk, V.; Detavernier, C.; Marin, G.B. CeO2-Modified Fe2O3 for CO2 Utilization via Chemical Looping. Ind. Eng. Chem. Res. 2013, 52, 8416-8426. [CrossRef]

126. Galvita, V.V.; Poelman, H.; Detavernier, C.; Marin, G.B. Catalyst-assisted chemical looping for CO2 conversion to CO. Appl. Catal. B 2015, 164, 184-191. [CrossRef]

127. Siriwardane, R.; Tian, H.; Richards, G.; Simonyi, T.; Poston, J. Chemical-Looping Combustion of Coal with Metal Oxide Oxygen Carriers. Energy Fuels 2009, 23, 3885-3892. [CrossRef] 
128. Hu, J.; Galvita, V.V.; Poelman, H.; Marin, B.G. Advanced Chemical Looping Materials for $\mathrm{CO}_{2}$ Utilization: A Review. Materials 2018, 11, 1187. [CrossRef] [PubMed]

129. Wang, X.; Du, X.; Yu, W.; Zhang, J.; Wei, J. Coproduction of Hydrogen and Methanol from Methane by Chemical Looping Reforming. Ind. Eng. Chem. Res. 2019, 58, 10296-10306. [CrossRef]

130. Galvita, V.V.; Poelman, H.; Marin, G.B. Hydrogen Production from Methane and Carbon Dioxide 1007 by Catalyst-Assisted Chemical Looping. Top. Catal. 2011, 54, 907. [CrossRef]

131. Mihai, O.; Chen, D.; Holmen, A. Chemical looping methane partial oxidation: The effect of the crystal size and O content of LaFeO3. J. Catal. 2012, 293, 175-185. [CrossRef]

132. Park, M.B.; Park, E.D.; Ahn, W.-S. Recent Progress in Direct Conversion of Methane to Methanol Over Copper-Exchanged Zeolites. Front. Chem. 2019, 7, 514. [CrossRef] [PubMed]

C 2020 by the authors. Licensee MDPI, Basel, Switzerland. This article is an open access article distributed under the terms and conditions of the Creative Commons Attribution (CC BY) license (http://creativecommons.org/licenses/by/4.0/). 